\title{
Molecular Gymnastics: Mechanisms of HIV-1 Resistance to CCR5 Antagonists and Impact on Virus Phenotypes
}

\author{
Michael Roche ${ }^{\mathrm{a}, \mathrm{b}}$, Katharina Borm ${ }^{\mathrm{b}, \mathrm{c}}$, Jacqueline K. Flynn ${ }^{\mathrm{b}, \mathrm{d}}$, Sharon R. Lewin ${ }^{\mathrm{a}, \mathrm{d}}$, Melissa J. \\ Churchill $^{\mathrm{b}}$ and Paul R. Gorry ${ }^{\mathrm{b}, \mathrm{d}, \mathrm{e}, \mathrm{f}^{*} \text {. }}$ \\ ${ }^{a}$ Peter Doherty Institute for Infection and Immunity, University of Melbourne, Melbourne, Australia; \\ ${ }^{b}$ Centre for Biomedical Research, Burnet Institute, Melbourne, Australia; \\ ${ }^{c}$ Department of Microbiology, Latrobe University, Melbourne, Australia; \\ ${ }^{d}$ Department of Infectious Diseases, Alfred Hospital and Monash University, Melbourne, Australia; \\ ${ }^{e}$ Department of Microbiology and Immunology, University of Melbourne, Melbourne, Australia; \\ ${ }^{f}$ School of Applied Sciences and Program in Metabolism, Exercise and Disease, Health Initiatives Research Institute, \\ RMIT University, Melbourne, Australia.
}

\begin{abstract}
Human immunodeficiency virus type 1 (HIV-1) enters host cells through the binding of its envelope glycoproteins (Env) to the host cell receptor CD4 and then subsequent binding to a chemokine coreceptor, either CCR5 or CXCR4. CCR5 antagonists are a relatively recent class addition to the armamentarium of anti-HIV-1 drugs. These compounds act by binding to a hydrophobic pocket formed by the transmembrane helices of CCR5 and altering the conformation of the extracellular domains, such that they are no longer recognized by Env. Maraviroc is the first drug within this class to be licenced for use in HIV-1 therapy regimens. HIV resistance to CCR5 antagonists occurs either through outgrowth of pre-existing CXCR4-using viruses, or through acquisition of the ability of CCR5-using HIV-1 to use the antagonist bound form of CCR5. In the latter scenario, the mechanism underlying resistance is through complex alterations in the way that resistant Envs engage CCR5. These significant changes are unlikely to occur without consequence to the viral entry phenotype and may also open up new avenues to target CCR5 antagonist resistant viruses. This review discusses the mechanism of action of CCR5 antagonists, how HIV resistance to CCR5 antagonists occurs, and the subsequent effects on Env function.
\end{abstract}

Keywords: HIV-1; Envelope; CCR5; Maraviroc; tropism; resistance

\section{INTRODUCTION}

\section{HIV-1 Entry}

Human immunodeficiency virus type 1 (HIV-1) entry into cells is mediated by the envelope glycoproteins (Env) that stud the surface of the virion [reviewed in [1] and [2]]. Env consists of two subunits, gp120 and gp41, and this heterodimer exists as a trimer embedded in the virus membrane. The gp120 subunit presents the outer face of Env, and contains a series of highly variable loops (V1-V5) and the receptor binding domains important for attachment to target cells. The gp41 subunit anchors Env to the virus membrane, and is mostly occluded

*Address correspondence to this author at the College of Science, Engineering and Health, RMIT University, 414-418 Swanston St, Melbourne 3083, Australia. Ph: +61-3-9925-0993. Email: paul.gorry@rmit.edu.au by gp120. It also contains the domains required for virus-cell fusion. The initial interaction between HIV-1 and a cell occurs between gp120 and the cell surface receptor CD4 [35]. Subsequently, structural rearrangements occur in gp120 that lead to exposure of the coreceptor binding sites and secondary binding to a chemokine receptor, either CCR5 [69] or CXCR4 [10]. This binding between gp120 and coreceptor causes further conformational changes in Env that leads to exposure of the fusion peptide of gp41 and insertion into the cell membrane. Fusion of the virus and cell membranes occur and the virion core is released into the cell cytoplasm.

HIV strains can be grouped by which coreceptor is utilized in the entry process [11]. Strains that use CCR5 are termed CCR5-tropic (R5); those that use CXCR4 are termed 
CXCR4-tropic (X4) and strains that can use either CCR5 or CXCR4 are termed dual-tropic (R5X4) [reviewed in [1, 12]]. The transmitted strains of HIV-1 are primarily R5, and R5 variants predominate in the early, or asymptomatic phase of disease [13-15]. In 40-50\% of HIV-1 subtype B infected individuals evolution of coreceptor usage leads to emergence of CXCR4-using variants, which is associated with increased CD4+ T-cell depletion and more rapid disease progression [16-19]. This is likely due to the expanded target cell repertoire available to $\mathrm{X} 4$ and $\mathrm{R} 5 \mathrm{X} 4 \mathrm{HIV}-1$, as a greater proportion of CD4+ T-cells express CXCR4 compared to CCR5 [1, 20, 21].

\section{The CCR5/Envelope interaction}

CCR5 is a G-protein coupled receptor consisting of 7 transmembrane helices (TM) and extracellular domains important for ligand binding. The extracellular domains consist of 3 loops (ECLs 1-3) and an N-terminal region. The ECL2 region is the primary site of chemokine binding specificity [22-24], although multiple regions including the N-terminus and ECL3 also appear important [25-31]. The binding of ligand to CCR5 is a two step process, with the chemokine core interacting with the CCR5 ECLs followed by binding of the amino terminus to a region formed by the transmembrane helices [25]. Interestingly, the binding of Env to CCR5 is also thought to be a two-step process. The current model of the gp120/CCR5 interaction has two distinct points of contact: 1) The binding of the CCR5 Nterminus to the stem of the gp120 V3 loop/ bridging sheet region and 2), the binding of the crown of the V3 loop with the CCR5 ECLs, in particular ECL2 [32-34]. For the former, sulfation of tyrosine residues in the CCR5 N-terminus is critical for binding of gp120 [29-31, 35, 36]. For the latter, a crystal structure of gp120 shows that the V3 loop extends $30 \AA$ from its base towards the cell membrane suggesting that it projects outward to contact the CCR5 ECLs [33]. Currently, it is unknown whether this is an ordered process, and if it is, which binding event occurs first. Furthermore, the relative dependencies of each binding event appear to be different for each gp120, and it is unknown if binding to one region is more favourable than the other. Intriguingly, deficiencies in binding to one site can be compensated by increased affinity for the other site. For example, an Env clone selected by passaging in a cell line expressing a mutant CCR5 with a deleted N-terminus had increased affinity for the CCR5 ECL2 [37]. Conversely, an Env clone with a deletion in the crown of the V3 loop (presumably abolishing interaction with ECL2) displayed increased dependence on the CCR5 N-terminus [38]. These studies demonstrate the significant degree of flexibility in the Env/CCR5 interaction.

\section{CCR5 ANTAGONISTS}

Individuals homozygous for a 32 base-pair deletion in the CCR5 gene (CCR5- $\triangle 32$ ) are relatively resistant to HIV-1 infection [39-42]. This is due to the absence of CCR5 expression in these people. Furthermore, those heterozygous for CCR5- $\triangle 32$ have reduced CCR5 expression which although not associated with reduced susceptibility to infection, is associated with slower disease progression [39,
42, 43]. Importantly, those carrying the $\Delta 32$ mutation appeared otherwise healthy suggesting that targeting CCR5 was a viable approach in inhibiting HIV-1 replication.

The first CCR5 antagonist described was TAK-779 from Takeda Chemical Industries. Complete inhibition of binding by CCR5 ligands RANTES (Regulated upon Activation Normal $\mathrm{T}$ cell Expressed) and MIP-1 $\alpha$ (Macrophage Inflammatory Protein) was achieved in the $\mathrm{nM}$ range. The compound inhibited the replication of HIV-1 R5 virus strains, but was not further developed due to its poor oral bioavailability [44]. Asn252 and Leu255 in TM6 of CCR5 were shown to be involved in the binding of TAK-779 [45]. Using molecular modelling and mutagenesis experiments, another study assigned a strong interaction between the aromatic side chain of Leu33, Tyr37, Tyr108 and Trp86 of CCR5 and TAK-779 [46, 47]. Other residues of CCR5 including, Thr195, Ile198, Phe109, Trp248, Tyr251 and Glu283 showed only weak interactions [46].

Following TAK-779 was TAK-220, a more potent CCR5 antagonist with an improved oral bioavailability. TAK-220 showed good anti-HIV activity with $\mathrm{IC}_{50}$ values in the low nM range [48, 49]. Antibody binding studies demonstrated the ability of TAK-220 to block the binding of mAb (monoclonal antibody) targeting the ECL2, but not mAb against the N-terminus of CCR5 [48]. TAK-779 in contrast could not inhibit binding of mAb to the ECL2 [50]; thus some interactions with CCR5 are different between TAK779 and TAK-220. TAK-220 is connected to Glu283 in TM7 via a salt-bridge and Ile198 in TM5 shows interactions of a hydrophobic nature. Additional amino acids; Phe109, Trp248 and Tyr251 are also in contact with TAK-220 [45, 46].

Simultaneously to the development of TAK-220, TAK-652 (Figure 1A; also known as TBR-652, cenicriviroc, CVC), a derivative of TAK-779, was developed. CVC is potently active against $\mathrm{HIV}-1$ with $\mathrm{IC}_{50}$ values lower than $1 \mathrm{nM}$, and demonstrates excellent pharmaceutical properties. Not only is TAK-652 a CCR5 antagonist, it also blocks the chemokine receptor CCR2b [48, 51]. CCR2 is involved in antiinflammatory actions through binding monocyte chemoattractant protein 1 (MCP-1), which is responsible for migration of monocytes [52]. CVC is in clinical development and progressed through phase IIb clinical testing in 2014. A clinical trial with treatment-naïve participants revealed concentrations between $50-200 \mathrm{mg}$ of CVC in combination with efavirenz were well tolerated [53]. A once-daily dose is sufficient as a consequence of CVC's long half-life [54, 55]. Little is known about the exact binding pattern of CVC within the CCR5 hydrophobic pocket.

Schering-Plough described the CCR5 antagonist SCH-C (SCH351125) in 2001 [56, 57], which had compelling antiviral activity against several HIV-1 subtypes and showed 
good pharmacological characteristics in mouse models and primates [57]. In clinical trials, it was discovered that SCH-C caused dose-dependent QTc (corrected QT interval) prolongations associated with moderate binding of hERG (human Ether-à-go-go-Related Gene) [58, 59]. SCH-C was followed by the more potent $\mathrm{AD} 101$, the precursor for vicriviroc (VVC, SCH-D and SCH417690). VVC (Figure 1B) is a compound with 6-times less affinity to hERG than SCH-C and displayed an improved CCR5 antagonism, as well as anti-HIV activity [59, 60]. Phase III studies are completed, but the drug was not approved for licencing after the studies showed no difference in viral load reductions whether VVC or placebo was added to an optimised background therapy in ART-experienced subjects [61]. VVC binds to the same pocket as the other small molecules mentioned earlier. The most important interactions are with Leu33, Tyr37, Trp 86, Tyr251, Ile198, Tyr108, Phe109, Thr195 of CCR5 and the electrostatic bonding with Glu283, similar to SCH-C $[46,47]$.

Maeda et al identified another small molecule AK602 (other names: aplaviroc, APL, ONO4128, GW873140), which was able to block the binding of MIP-1 $\alpha$ and HIV-1 strains with an $\mathrm{IC}_{50}$ below $1 \mathrm{nM}$, without affecting RANTES- or MIP-1ßbinding [62]. Furthermore, APL (Figure 1C) demonstrated favourable pharmacokinetics in rodents [63]. In early human trials however, APL caused several severe cases of hepatotoxicity, and thus, the clinical development of APL was terminated after phase 3 testing [64]. Additional to the amino acids in the hydrophobic cavity mentioned earlier, APL may also interact with Lys191 or the Lysine on position 26 at the base of the CCR5 N-terminus [47].

Currently, many research groups are developing, synthesizing or identifying new CCR5 antagonists with a potent anti-HIV activity; 16g, B07 and GSK214096 are just some of them [65-67].

\section{Maraviroc}

UK427,857 (Figure 1D) was discovered by Pfizer through a large compound screen and was later renamed maraviroc (MVC). It is a potent and specific CCR5 antagonist as well as an efficient anti-HIV compound with a mean $\mathrm{IC}_{50}$ of $2 \mathrm{nM}$ $[68,69]$. The clearance by the US FDA and the EU for treatment-experienced individuals occurred because of excellent pharmacokinetics and a positive outcome of the phase III trials (MOTIVATE-1, 2) [70-72]. Phase III trials with treatment-naïve individuals demonstrated safety and efficacy only after a post-hoc analysis that excluded participants with CXCR4-using virus based on a more sensitive tropism assay [73]. Subsequent to this, MVC was licensed for treatment-naïve patients by the US FDA in November 2009 [74]. MVC binds in the hydrophobic pocket and interacts with Glu283 over a salt-bridge. Other amino acids including Trp86, Tyr108, Phe109, Ile198 and Tyr251 are also involved [46, 47]. In 2013, Tan et al crystallized MVC bound to the chemokine receptor CCR5, which confirmed the interaction between the mentioned amino acids and CCR5 [75].

\section{Mechanism of Action}

Many studies showed that these small-molecules are able to inhibit HIV-1 entry by blocking the binding of gp120 to CCR5 [44, 48, 50, 68, 76]. All CCR5 entry inhibitors target the same hydrophobic cavity formed between the transmembrane domains 1, 2, 3, 5, 6 and 7 [46, 47, 50, 7578]. However, the binding profile of each of the drugs differs slightly from each other $[46,47]$, suggesting that the binding mechanism is related although not overlapping [50]. Thus, the CCR5 antagonists described do not appear to bind to regions critical to HIV-1 binding. Furthermore, one study showed that there is no direct contact between MVC and the ECL2 of CCR5 [75]. However, gp120, RANTES, MIP-1 $\alpha$ and MIP-1ß rely on the optimal conformation of ECL2 [23, 25]. Evidence of the affect of antagonist binding to CCR5 is provided by CCR5-specific antibody binding studies. For example, AD101 and SCH-C specifically block the binding of ECL2-directed antibodies [50]. A study by Tilton et al showed that MVC, APL, VVC and TAK-779 blocked the binding of ECL-specific antibodies but not antibodies directed against the CCR5 N-terminus [79]. Therefore, to surmise, all CCR5 antagonists bind within the same hydrophobic cavity, each compound in a unique way. The binding introduces conformational changes in the ECL2 of CCR5 but not the CCR5 N-terminus, inhibiting the binding of gp120 and therefore blocking HIV-1 entry. This evidence demonstrates that CCR5 antagonists act as allosteric inhibitors of the HIV-1 Env/CCR5 interaction.

Tamamis et al published an interesting study in 2014, where the authors compared the MVC-CCR5 crystal structure [75] with the first molecular dynamics simulation of CCR5 in complex with an R5X4 gp120 V3 loop. This study revealed that CCR5 antagonists prevent the V3 crown of gp120 from binding in the transmembrane region because gp120 and the small molecule share similar interaction partners such as Tyr37, Tyr108, Thr251 and Glu283 [78]. These findings suggest that in addition to allosteric inhibition of gp120 binding, MVC may directly inhibit gp120 binding to CCR5.

Interestingly, MVC not only blocks the binding of gp120, it also is able to induce the release of gp120 after it is bound to CCR5 [80]. In comparison, CVC seems to hold gp120 at the chemokine receptor without releasing it into the plasma. Kramer et al suggests this reaction is due to a deeper and different binding of CVC compared to MVC into the hydrophobic cavity [81].

\section{Tropism Testing: An important component of the clinical use of CCR5 antagonists}


As CCR5 antagonists have no activity against X4 HIV-1, a tropism test must be performed prior to initiation of therapy. The tropism test determines the coreceptor usage of virus present in patient plasma samples and ensures that only patients with R5 HIV-1 are given these drugs. Tropism tests fall into two categories; genotypic tests and phenotypic tests. Genotypic tests detect R5 and X4 HIV-1 via sequencing and analysis of the V3 loop of gp120. Initial tests used simple rules such as overall charge of the V3 loop and presence of charged amino acids at position 11 and 25 within the loop [82-85]. More complex algorithms such as geno2pheno [86] and WEBPSSM [87] use combinations of rules and have greatly improved the predictive power of genotypic tests. Furthermore, subtype specific algorithms have been designed leading to greater predictive power across the majority of HIV-1 subtypes [88, 89]. Use of genotypic tests is advantageous as they are cost-effective, have a short turn around time and can be performed by most diagnostic laboratories. However, genotypic tests also have two major limitations. First, whilst the V3 loop is the primary determinant of coreceptor specificity [90-93], other regions within the HIV-1 Env protein including the other variable loops regions of gp120 and regions within gp41 can influence coreceptor usage [94-96]. Second, bulk sequencing is not sensitive enough to detect minority populations of X4 HIV-1 that may be clinically significant. However, the application of novel deep sequencing technologies, in combination with modern predictive algorithms, has greatly improved the sensitivity and specificity of genotypic tests [97-99].

Phenotypic tests for HIV-1 tropism require the bulk cloning of Env followed by the phenotypic assessment of coreceptor usage. This is typically performed by the creation of Envpseudotyped reporter viruses and infection of cell lines expressing CD4 and either CCR5 or CXCR4. The first of these phenotypic tropism tests was the Trofile assay ${ }^{\mathrm{TM}}[100]$. This test uses luciferase reporter viruses pseudotyped with Envs amplified from plasma, and has the ability to detect CXCR4-using variants at a frequency as low as $10 \%$ of the viral swarm. Used in clinical trials of MVC, VVC and APL, Trofile was considered the 'gold standard' for tropism testing of HIV-1 [71, 101]. However, evidence from clinical trials of MVC and VVC indicated that the $10 \%$ sensitivity of the Trofile assay was insufficient, as CXCR4-using variants that were present below the detection limit of the assay were responsible for a significant amount of resistance to these drugs [73]. Reanalysis of these samples using an enhancedsensitivity Trofile assay (ESTA) [102], which has a sensitivity of $0.3 \%$ for the detection of CXCR4-using variants, confirmed the presence of CXCR4-using variants in up to $26 \%$ of those originally classified as CCR5-tropic [103, 104]. The use of the ESTA assay prior to initiation of CCR5 antagonist therapy improves the outcomes for MVC- and VVC-containing regimes [73, 104]. However, the Trofile and enhanced Trofile test both suffer from the same limitations; these tests are expensive, time consuming and cannot be performed by typical diagnostic laboratories. Furthermore, these tests require relatively high levels of plasma HIV-1 RNA (>1000 copies/mL) and, thus are not suited for virally suppressed patients requiring a switch in therapy regimens.

Given the logistical and cost advantages of genotypic assays, multiple studies have examined the performance of these algorithms against the Trofile assay from the clinical trials of both MVC and VVC. High concordance has been observed between the performance bulk sequencing with geno2pheno or PSSM and that of Trofile in predicting CXCR4-using viruses [105-108]. The use of deep sequencing in conjunction with geno2pheno shows high concordance in prediction of CXCR4 usage compared to Trofile [109, 110] and ESTA [111]. Thus, whilst ESTA remains the 'gold standard' assay for HIV-1 coreceptor tropism determination, genotypic assays combined with either bulk or deep sequencing show a similar, if not improved performance, and are likely to become more commonly used in the clinic prior to CCR5 antagonist usage. Indeed, European guidelines for treatment recommend use of bulk sequencing and geno2pheno for tropism testing in patients with high ( $>1000$ copies/mL) and low (<1000 copies/mL) viral loads [112].

Recent evidence suggests that both the Trofile assay and genotypic assays can be adapted to use cell associated HIV-1 DNA [107, 113-116]. The viability of these tests will allow the use of MVC in patients with suppressed viremia $(<50$ copies/mL), making these drugs viable for switch regimens.

\section{Resistance to CCR5 antagonists: In vitro}

Although the CCR5 antagonists target a host cell protein rather than a viral protein, HIV-1 resistance can still occur. When faced with blockade of CCR5, the most intuitive pathway of escape for HIV-1 would be by changing coreceptor usage to CXCR4, thus making the blockade of CCR5 irrelevant. This is potentially clinically important, as the emergence of X4 HIV-1 variants in vivo is associated with a more pathogenic virus that rapidly accelerates disease progression [16-19]. Therefore, a major concern with CCR5 antagonists is the potential for accelerated CD4+ T-cell depletion as a consequence of drug resistance through coreceptor switching.

Trkola et al were the first to describe the in vitro generation of a CCR5 antagonist resistant virus [117]. The R5 clinical isolate CC1/85 used in this study, whilst CCR5 using, switched to CXCR4 usage within 6 months in vivo [19]. Using an isolate with a demonstrable ability to switch coreceptor usage would therefore remove any bias from the study. CC1/85 was passaged in increasing concentrations of AD101 in PBMCs, and by passage 16 an isolate arose that was able to replicate in high concentrations of AD101. Analysis of this isolate showed that resistance mapped to the Env protein, as would be expected. Interestingly, rather then switching to CXCR4 usage when faced with CCR5 blockade, the resistant isolate remained CCR5 tropic and was unable to use any other alternative coreceptor for HIV-1 entry. The mutations in Env required for resistance were 
mapped to 3 amino acid changes in the V3 loop [118]. Westby et al used the same isolate to generate resistance to a different CCR5 antagonist, MVC [119]. After 18 passages in PBMC a fully resistant isolate emerged. As with the AD101resistant variant of $\mathrm{CC} 1 / 85$, this isolate remained CCR5 tropic, but resistance was mapped to 2 amino acid changes in the V3 loop that were different to those observed in the previous study. Several other studies have generated CCR5 antagonist resistant HIV-1 variants to VVC [120-122], MVC [123] and CVC [124]. These extensive studies have characterized the phenotypes of CCR5 antagonist resistant viruses and several common and important properties have arisen.

First, resistance to CCR5 antagonists is not through switching of coreceptor use to CXCR4 or an alternative coreceptor [117, 119-121, 124]; resistant viruses continue to use CCR5 in a drug insensitive manner. Second, the amino acid changes necessary for resistance typically map to the V3 loop of gp120 [118, 119, 121]. This is to be expected, as the V3 loop is primarily responsible for interacting with CCR5. However, mutations outside of the V3 loop, including the C2 and C4 regions of gp120 and even gp41 have been reported [124-127]. Furthermore, there are no consistent 'signature' amino acid mutations associated with resistance to CCR5 antagonists and mutations appear to be context dependent, with these mutations generally unable to confer resistance when introduced into another genetic HIV-1 background $[121,126]$. These results suggest that the arising resistance mutations are strain specific, and thus, the use of genotypic tests to diagnose resistance to CCR5 antagonists is unlikely to be effective.

Finally, the way in which resistance manifests itself is unique to CCR5 antagonists. Typically, resistance to HIV-1 ARVs is characterised by shifts in the $50 \%$ inhibitory concentration $\left(\mathrm{IC}_{50}\right)$ and is a form of competitive resistance. However, when CCR5 antagonist resistant viruses are assayed for drug sensitivity, shifts in $\mathrm{IC}_{50}$ are not typically observed. Rather, plateaus below $100 \%$ of maximal inhibition are observed [119, 121, 128, 129]. These plateaus are not affected by further increases in drug concentration and represent a non-competitive mechanism of resistance [130]. The plateau, or maximal percent inhibition (MPI) is now considered a marker for R5 HIV-1 resistance to CCR5 antagonists.

Besides being a marker for resistance, the MPI is also informative of the mechanisms that underlie resistance. The fact that the MPI remains stable despite increases in drug concentration to levels far exceeding those that are saturating, suggests that resistant viruses are binding to the drug-occupied conformation of CCR5. The hypothesis that resistant viruses have developed the ability to recognize, bind to and utilize the drug/CCR5 complex for entry has been confirmed in multiple CCR5 ligand/inhibitor combination studies [119, 128]. The MPI also describes the efficiency at which resistant viruses can use the drug/CCR5 complex compared to free receptor; with viruses that recognise the complex less efficiently having a comparatively high plateau of inhibition (>80\% MPI), whilst viruses that recognise the complex efficiently having a comparatively low plateau ( $<20 \% \mathrm{MPI})$. The cell type used in the sensitivity assay appears to affect the MPI as well, with some cell lines yielding lower plateaus compared to other cell lines [129, 131, 132]. This has been related to the expression levels of CCR5, with cell lines expressing high levels of CCR5 typically providing lower MPIs [129, 131, 132], suggesting that resistant viruses have an increased ability to utilize the drug/receptor complex when there is more of the complex at the cell surface. To further complicate matters, primary cell types such as PBMCs typically produce much lower plateau heights, even negative plateaus suggesting drug enhanced entry, compared to cell lines $[119,126]$. The mechanisms that determine the peculiar resistance profiles generated in primary cells are unknown, although expression of isoforms of CCR5 with differing drug/Env affinities have been postulated [126, 133].

In order to recognize the drug/receptor complex, the amino acid mutations in Env that are responsible for resistance must alter the way gp120 interacts with CCR5. Several studies have now examined the mechanism of interaction with CCR5 by CCR5 antagonist resistant viruses generated in vitro. The majority of resistant viruses appear to become heavily reliant on the CCR5 N-terminus for viral entry [38, 127, 132, 134]. This extracellular region of CCR5 does not appear to be altered by CCR5 antagonists [79], and perhaps represents the resistant viruses strengthening an interaction with a region of CCR5 that is not modified by the drug. Studies using antibodies targeting the CCR5 $\mathrm{N}$-terminus also confirm the increased importance of this region of CCR5 for the interaction with CCR5 antagonist resistant viruses [38, 127]. In addition, altered contacts with the ECL regions may also be required [132, 135]. Therefore, in vitro escape from CCR5 antagonists by R5 HIV-1 involves recognition of the drug/receptor complex, enabled through mutations in gp120 that enhance the interaction with the CCR5 $\mathrm{N}$-terminus and possibly an altered binding to the CCR5 ECLs.

\section{Resistance to CCR5 antagonists: In vivo}

There is significant evidence available from clinical trials of MVC, VVC and APL to suggest that compared to when HIV-1 becomes resistant to CCR5 antagonists in vitro, the situation is more complex in vivo. Combined analysis of the two phase-III trials of MVC in treatment-experienced patients (MOTIVATE-1 and -2) showed that the predominant reason for failure of therapy is through emergence of CXCR4-using HIV-1 variants. Indeed, $57 \%$ of virological failures occurred with an X4 or DM (dual mixed) tropism result [70]. Lower, but significant frequencies of X4 HIV-1 emergence in virological failures were seen in the MERIT phase-III MVC trial in treatment-naïve patients (31\%) [73], and in phase-II VVC trials with treatmentexperienced patients (44\%) [136] and treatment naïve patients (19\%) [101]. Virological failure associated with the 
emergence of X4 HIV-1 has also been observed in clinical trials of APL $[137,138]$. Interestingly, the lowest frequencies of the emergence of X4 HIV-1 associated with virological failure was observed in the large phase-III VVC trial in treatment-experienced patients (VICTOR E3 and E4), with only $17.5 \%$ and $19 \%$ of virological failures having a X4 or DM tropism result [61]. Importantly, this trial used the more sensitive ESTA to screen patients for coreceptor tropism, indicating that at least a proportion of $\mathrm{X} 4$-associated virological failures could be attributed to minority $\mathrm{X} 4$ variants not detected in the initial tropism screening using the less sensitive Trofile assay.

Multiple studies have subsequently examined whether the emergence of X4 HIV-1 during treatment with CCR5 antagonists is from genuine coreceptor switching or from pre-existing minority CXCR4-using variants not detected by the initial tropism screening. Using ultra-deep sequencing, one study evaluated viral coreceptor usage from four patients who failed VVC therapy with X4 HIV-1. It was discovered that the V3 loop mutations associated with X4-tropism were present at very low frequencies $(0.8-2.8 \%)$ prior to treatment with VVC [97]. Westby et al demonstrated that in two patients failing MVC therapy with X4 HIV-1, the CXCR4using variants were derived from a pre-treatment reservoir [139]. Using ultra deep sequencing combined with genotypic prediction software, Swenson et al demonstrated that pretreatment X4 HIV-1 could be detected in $70 \%$ of non-R5 failures in a subset of the MOTIVATE trial [140]. These studies show that the emergence of X4 HIV-1 during treatment with CCR5 antagonists is likely from a pretreatment source undetected by the baseline tropism screen rather then from genuine coreceptor switching of CCR5using viruses. Furthermore, several studies have shown that the CXCR4-using variants that emerge during treatment with CCR5 antagonists appear to be less fit, as CD4+ T-cell counts increased or remained stable despite the rebound in viral load associated with emergence of X4 HIV-1 strains $[70,136]$, and these variants rapidly disappear after cessation of therapy [139].

Despite the in vitro demonstration of genuine resistance by R5 HIV-1 to CCR5 antagonists, evidence from clinical trials suggests that this is not the most common cause of virological failure with R5 HIV-1. Only 40\% of R5-virologic failures in the MVC phase-III trials were associated with reductions in MPI [141]. For the remaining 60\% of failures that remain sensitive to MVC, the reason for failure is unknown but may be due to poor drug adherence or HIV-1 resistance to the background therapy regimen [141]. Only $4 \%$ of virological failures in the VVC phase-III trials had demonstrable VVC resistance [142]. Similarly, low percentages of genuine R5 resistance to CCR5 antagonists were observed in phase-II trials of VVC and APL [136, 138, 143-145].

In agreement with the in vitro studies, several studies have demonstrated that genuine resistance to CCR5 antagonists is not characterized by increases in $\mathrm{IC}_{50}$, but rather through reductions in MPI [79, 131, 138, 144, 146-149]. This is suggestive that, like in vitro generated viruses, resistance to CCR5 antagonists in vivo is through continued use of the drug receptor complex [131]. Again, in agreement with in vitro reports, there appears to be no consistent pattern of genetic mutations associated with resistance [144, 145, 149, $150]$, and the mutations are mostly strain-specific [144, 145, 151]. The majority of the mutations required for resistance have been mapped to the V3 loop of gp120 [79, 146-149, 152]. However, in many cases, the magnitude of resistance is modulated by changes outside of the V3 loop including the V4 loop, C4 region and gp41 [79, 148, 152]. Taken together, these studies demonstrate the complexity of mutations associated with R5 HIV-1 resistance to CCR5 antagonists in vivo, and may explain the relatively low frequencies of resistance seen with the use of these drugs clinically.

Like resistant viruses generated in vitro, resistance to CCR5 antagonists in vivo involves alterations in the way gp120 interacts with CCR5. Several studies have demonstrated a critical reliance on the CCR5 $\mathrm{N}$-terminus by Envs derived from resistant isolates [79, 148, 149, 152, 153], and increased sensitivity to inhibition by antibodies targeting the CCR5 N-terminus [148]. Other reports have also highlighted critical contacts in the ECLs [79, 135, 148, 149]. These results suggest much like the data generated in vitro, mutations both within and outside of the V3 loop permit entry by use of the antagonist-modified form of CCR5. These changes both within V3 and outside of it presumably alter the conformation of the coreceptor binding sites, allowing for an altered recognition of the CCR5 extracellular domains. Resistance mutations may also increase the number of bonds formed between Env and the CCR5 N-terminus, strengthening this interaction [148, 149]. Additionally, resistance mutations may lock Env into a pre-triggered conformation lowering the activation energy required and/or permitting a weakened or reduced binding to CCR5 to be sufficient to induce the Env fusion cascade.

\section{Baseline resistance to CCR5 antagonists}

The gp120/CCR5 interaction is remarkably flexible, as shown by the afore-mentioned studies of HIV-1 resistance to CCR5 antagonists and the large range of effects that CCR5 mutations have in attenuating HIV-1 entry by panels of primary Envs [154-156]. It is interesting to speculate that there may exist, in nature, HIV-1 Env variants in CCR5 antagonist therapy naïve individuals that are able to recognize, bind to and use antagonist-modified forms of CCR5. This potentially has clinical importance, as the presence of these variants pre-treatment could potentially lead to rapid outgrowth of resistant virus and render treatment with CCR5 antagonists ineffectual. Baseline resistance to the CXCR4 antagonist AMD3100 has been demonstrated in lab adapted and primary CXCR4-using HIV-1 Envs, presumably through an altered engagement with CXCR4 [157]. Therefore, it may be important to determine whether HIV-1 variants exist that can utilize 
altered conformations of CCR5 and if this is indeed relevant in the setting of CCR5 antagonist therapy.

In the pre-clinical development of MVC, Dorr and colleagues screened $200 \mathrm{HIV}-1$ isolates, including isolates from multiple HIV-1 clades and were unable to detect any reduced sensitivity or resistance [68]. Strizki et al screened 21 genetically diverse HIV-1 isolates during development of SCH-C and found one clade G isolate (RU570) that displayed significantly reduced sensitivity to SCH-C, with a 200 fold higher $\mathrm{IC}_{50}$ than average [57]. Interestingly, this isolate demonstrated an ability to generate CCR5 antagonist resistant Envs in several in vitro passaging studies [119, 121]. Delobel et al screened 14 isolates harbouring potential V3 MVC resistance mutations along with 14 control isolates and found one isolate with reduced MPI to MVC [158]. We investigated an envelope clone from the CC1/85 isolate, which readily evolves resistance to CCR5 antagonists in vitro [159]. In cell lines expressing low to medium levels of CCR5 (similar to those used in clinical assays for coreceptor tropism) this Env displayed complete sensitivity to MVC. However, in cell lines engineered to express high levels of CCR5, such as 293-Affinofile cells [160] reductions in MPI to MVC could be seen. Subsequent to this, use of high CCR5 expressing cells has revealed the presence of Envs in subtype $\mathrm{C}$ infections capable of using antagonist bound CCR5 in significant proportions [161, 162]. These results demonstrate that HIV-1 variants exist that are able to recognize the drug modified form of CCR5 to some degree, and as a consequence of this, could more readily evolve to become fully resistant under drug selection pressure. This was shown to be clinically relevant in a study on viruses isolated from an individual that had rapidly failed APL therapy $[137,138]$. In a study of Envs cloned from this patient, it was discovered that those cloned from the pre-treatment isolate demonstrated the characteristic resistance profile of reduced MPIs to APL [131]. Thus, resistance to APL was pre-existing in this patient, and as a consequence, rapid virological failure occurred on APL therapy. Use of ultra-deep sequencing technology for isolates from patients failing CCR5 antagonist therapy has revealed the presence, at low frequencies in the pre-treatment viral populations, of gp120s with at least 1 or 2 amino acid polymorphisms determined to be important for resistance [79, 97, 147]. These variants were rapidly selected for, suggesting they had a replicative advantage and most likely a weak ability to recognise the drug/receptor complex, and acted as a scaffold for additional mutations to confer complete resistance [147]. It is unknown whether the presence of pre-existing, partially resistant variants is required for the generation of HIV-1 resistance to CCR5 antagonists or if genuine resistance can evolve under drug pressure. Further retrospective studies on HIV-1 isolates from individuals who have failed CCR5 antagonist therapy are required to determine which pathway to resistance is the dominant pathway, and whether current tropism assays can be modified to help detect pre-existing resistance to CCR5 antagonists, possibly through using cell lines that have much higher levels of CCR5 expression.

\section{CONSEQUENCES OF HIV-1 RESISTANCE TO CCR5 ANTAGONISTS}

As discussed, in order to become resistant to CCR5 antagonists, considerable flexibility in coreceptor engagement is required by HIV-1 gp120. This likely comes through altered binding of CCR5, as a result of structural changes in Env. Such significant structural changes and receptor interactions are unlikely to occur without consequences for the virus, and what this potentially means in regards to changes in viral phenotype is discussed below.

\section{Viral Fitness}

Differences in the phenotype of HIV-1 Env proteins, such as the ability to scavenge low levels of receptors on the cell surface and entry kinetics, can have a profound affect on replication and viral fitness $[163,164]$. Therefore, changes in gp120 as a consequence of resistance to CCR5 antagonists may alter the efficiency of the entry process and affect the overall fitness of HIV-1.

An effective way to measure the fitness of drug resistant mutants derived in vitro is to continue to passage these variants in the absence of drug. If the drug resistance mutations do not reduce fitness then they should, in theory, remain in the viral swarm. If the mutations do affect viral fitness, then those variants will rapidly disappear, either by being out-competed by drug-sensitive variants or reversion to the sensitive phenotype through back mutations. In a study on clade B (CC1/85) and clade G (RU570) MVC-resistant viruses generated in vitro, continuation of viral passaging in the absence of MVC lead to complete reversion of the sensitive phenotype for RU570 [119]. The three amino acid insertion in the V3 loop of the gp120 of RU570 that was sufficient to confer resistance to MVC was not detected in the revertant viral swarm, and all 12 individual Env clones from the culture displayed complete MVC sensitivity. For CC1/85, one of two amino acid mutations in the V3 loop of gp120 reverted back to the sensitive phenotype, whilst the second mutation remained. Interestingly, the retained resistance mutation was present at low frequencies in the parental culture to begin with. All but two Env clones from the revertant culture displayed complete sensitivity to MVC. Compared to this, Trkola et al and Anastassopoulou et al described an AD101-resistant virus [117, 165] where despite passaging in the absence of drug, the resistant genotype and phenotype were maintained. In head-to-head fitness studies, the AD101-resistant virus was not out-competed by the inhibitor-sensitive parental virus. These results are suggestive that, at least in vitro, fitness costs associated with resistance to CCR5 antagonists are probably strain- and drug-dependent.

Currently, little is known about the fitness of CCR5 antagonist resistant viruses derived from patients failing therapy. Viral fitness requirements in vivo are likely to be very different considering the immune pressures and heterogeneous target cell populations faced by escape 
mutants. Discontinuing VVC in a patient who had developed resistance led to a loss of the V3 loop resistance mutations and reversion to VVC sensitivity [146]. Similar results where discontinuing drug has led to reversion of the sensitive phenotype have been reported for the viral fusion inhibitor T-20, and this has been related to fitness defects in the resistant strains $[166,167]$. Taken together, these results suggest that resistance to HIV-1 entry inhibitors in patients can lead to attenuation of viral fitness, although there will need to be more studies to determine if this is clinically relevant.

\section{Cross-resistance}

Several studies have shown that CCR5 antagonist resistant viruses generated in vitro do not display cross-class resistance, such as resistance to NRTIs, NNRTIs and PIs $[120,168]$. This is to be expected, as resistance to CCR5 antagonists is modulated through the Env protein and drugs from other classes act at different stages of the viral life cycle, compared to entry inhibitors. Thus, although crossclass resistance is unlikely, there remains the possibility that CCR5 antagonist resistant viruses may be cross-resistant to other entry inhibitors that act at the same stage (other receptor inhibitors) or a similar stage (fusion inhibitors) of the viral life cycle.

Several reports of CCR5 antagonist resistant viruses generated in vitro have shown that resistance does not lead to cross-resistance to the fusion inhibitor T-20 [119, 120, 129, 168]. This effect is mirrored in vivo [79, 131, 146], and likely means that the changes required for resistance to CCR5 antagonists, which predominate in the V3 loop of gp120, do not occlude the binding site for T-20 (i.e., the HR1 region of gp41) or increase the efficiency of gp41mediated HIV-1 fusion. Interestingly, for a MVC resistant virus generated in vitro, increased sensitivity to T-20 was seen in the presence of saturating concentrations of MVC $[119,135]$. This suggests that for this virus, the use of the drug/receptor complex is associated with a reduced rate of virus-cell fusion and potentially a less efficient entry process overall. Resistance to CCR5 antagonists is also not associated with resistance or reduced sensitivity to the natural ligand of CCR5, RANTES [128, 146]. RANTES operates by competing with gp120 for binding to CCR5 and once bound, induces internalization of the coreceptor [169]. Other studies have shown that resistance to CCR5 antagonists is not associated with resistance or reduced sensitivity to drugs that block the gp120/CD4 interaction, including CD4-IgG2 [120] or BMS-806 [168]. Taken together, these studies suggest that resistance to CCR5 antagonists does not lead to cross-resistance to other HIV-1 entry inhibitors.

Whilst resistance to entry inhibitors of other sub-classes is not seen when HIV-1 acquires resistance to CCR5 antagonists, significant cross-resistance is observed against other CCR5 antagonists. This has been observed for resistant viruses generated in cell culture $[117,118,120,168]$ and for resistant viruses isolated from patients failing therapy with CCR5 antagonists [131, 146, 147]. Therefore, although the various CCR5 antagonists affect the CCR5 ECL conformations in subtly different ways, many resistant viruses are able to tolerate this. However, cross-resistance to CCR5 antagonists is not always the case with several isolates showing a narrow resistance profile [79, 119, 149]. Interestingly, in these cases where a lack of cross-resistance was observed, the selecting compound was MVC. These studies suggest that the requirement for recognition of the MVC-modified ECLs is different to other drug-modified forms of CCR5, and also suggests that the CCR5 conformations induced by MVC may be unique. Further study is required to address whether MVC resistant viruses universally display this narrow resistance profile.

\section{Sensitivity to HIV-1 Neutralizing Antibodies}

The Env glycoprotein is the major target of the neutralizing antibody (Nab) response to HIV-1, therefore raising the possibility that changes in Env as a result of escape from CCR5 antagonist pressure may cause changes in sensitivity to Nabs. In a study on AD101- and VVC- resistant viruses, Pugach et al described the neutralization sensitivity consequences of CCR5 antagonist resistance [168]. The AD101-resistant Env, where the resistance mutations were mapped to the V3 loop of gp120, was more sensitive to neutralization by the monoclonal antibodies 2G12 (glycanspecific, binds to gp120 carbohydrates) and 2F5. Both resistant Envs had increased sensitivity to sera from HIV-1 infected individuals, with the AD101-resistant Env more so. A follow-up study showed that this Env was also more sensitive to the monoclonal antibodies $17 \mathrm{~b}$ and $48 \mathrm{~d}$, which have epitopes in the bridging sheet of gp120 that are induced by gp120 binding to CD4, and V3 loop directed antibodies 19b, 2.1e and 447-52D [134]. A MVC resistant Env generated in vitro was more susceptible to antibodies targeting the CD4 binding site, a CD4-induced epitope, the V3 loop and autologous plasma IgG's [170].

Kramer et al investigated the sensitivity of lab-derived viruses to broadly neutralizing antibodies after exposure to MVC. This study firstly demonstrated a change in the infectiousness of lab-derived HIV-1 strains (AD8, CC1/85) which had previously been exposed to MVC. HIV-1 BaL previously exposed to MVC showed a reduced sensitivity to gp120-specific antibodies, b12 (CD4 binding site of gp120) and VRC01 (CD4 binding site antibody). The effect of preexposure of CC $1 / 85$ to MVC decreased sensitivity to 2G12, whereas MVC-exposed AD8 retained is resistance to 2G12 and 4E10 with sensitivity to neutralization dependent upon antibody concentration. These results suggest that preexposure to MVC was able to alter HIV-1 susceptibility to broadly neutralizing antibodies, although changes to neutralization were virus specific. 
Very little is known about Nab sensitivity of resistant Envs from patients failing CCR5 antagonist therapy. A MVC resistant Env was shown to have increased sensitivity to the b12 Nab, but reduced sensitivity to 2G12 [79]. Further studies are required to determine the antibody neutralization sensitivities of CCR5 antagonist resistant viruses, especially those generated in vivo, as these evolve under the pressure of the humoral immune response [171]. Currently, neutralization sensitivity appears to be strain specific and probably related to where the resistance mutations map to, be it the V3 loop or other regions of gp120.

\section{Efficiency of receptor usage}

Several studies have shown that resistant viruses with high MPIs have a reduced efficiency of CCR5 usage [129, 132, 152]. However, resistant viruses with low MPIs tend to show no reduction in the efficiency of use of the drugmodified form of CCR5 [79, 149]. These differences are probably strain specific, with some HIV-1 Envs more readily able to tolerate rearrangements in the interaction with CCR5. Evidence suggests that the efficiency at which HIV-1 engages with receptors for entry may increase as disease progresses [155, 164, 172, 173], and that this is associated with enhanced replicative capacity [174], and expanded cell tropism [164], but not increased likelihood of evolving resistance to CCR5 antagonists in culture [175]. It is interesting to speculate whether the reverse holds true for CCR5 antagonist resistant viruses, with reduced efficiency of receptor usage.

\section{Changes in Cellular Tropism}

Studies have shown that altering the mechanism of coreceptor engagement by CCR5 antagonist resistant viruses can alter the cellular tropism of HIV-1. One study examining HIV-1 resistance to APL showed that a viral variant with relatively inefficient usage of APL-bound CCR5 had an altered $\mathrm{CD}^{+} \mathrm{T}$ cell tropism [152]. In the presence of APL, resistant viruses were demonstrated to have an increased CCR5 dependence which indicated a less efficient recognition of the APL-modified CCR5 compared to free receptor forms. The change in $\mathrm{T}$ cell tropism showed a reduction in the infection of central memory (CM) $\mathrm{CD}^{+} \mathrm{T}$ cells [152]. This change in $\mathrm{CD}^{+} \mathrm{T}$ cell tropism could be important as the destruction of CM cells have been associated with HIV-1 disease progression [176, 177] and CM cells have been shown to be a viral reservoir for HIV-1 [178]. One possible reason for the reduction of infection of CM cells may be associated with the increased dependence on CCR5 from resistant viruses as CM cells have a lower expression of CCR5 on their surface compared to EM cells [179-183] which may have contributed to a relative sparing of this subset.

In a study using a MVC-resistant strain generated in-vitro, we showed a reduction in monocyte-derived macrophage (MDM) infectivity due to inefficient recognition of MVCbound CCR5 expressed on the macrophage surface [132].
This study found the MVC resistant strain to become dependent upon the CCR5 N-terminus and on positively charged elements of the drug-modified CCR5 ECL1 and ECL2 regions [132]. This altered mechanism of CCR5 engagement caused an attenuation in the entry of HIV-1 into MDM, also cell-cell fusion activity with MDM and reduced the viral replication capacity in MDM. These two drug resistance studies, APL resistance in CD4+ T cells and MVC resistance in macrophages, could suggest that a continuation of CCR5 antagonist therapy, even after resistance had developed, may maintain a selection for variants that use CCR5 inefficiently for entry and could possibly spare or reduce the infection of HIV-1 cellular reservoirs.

In a further study of MVC resistance, we examined cellular tropism changes in CD4+ $\mathrm{T}$ cell subsets and macrophages using viral envelopes from two MOTIVATE phase III clinical trial subjects who developed MVC resistance in vivo. Envs isolated from one subject displayed an efficient recognition of MVC-bound CCR5 whilst Envs isolated from the other had a relevantly inefficient recognition [149]. This study allowed the investigation into whether attenuation for cellular targets, in particular $\mathrm{CM} \mathrm{CD} 4^{+} \mathrm{T}$ cells and macrophages, was common for all MVC resistant viruses or whether it was associated with the level of efficiency of usage of MVC-bound CCR5. Cellular tropism assays revealed MVC-resistant Envs with efficient recognition of MVC-bound CCR5 had an increased infection of CM CD4 ${ }^{+}$ $\mathrm{T}$ cells and a significant reduction in infection of EM and TM cells and no change in macrophage infectivity [180]. In contrast, MVC-resistant Env with an inefficient usage of MVC-bound CCR5 display no change in T cell tropism but had a significant reduction in macrophage infectivity. This study suggested the cellular tropism of MVC-resistant viruses can vary and may be affected by the efficiency of the usage of MVC-bound CCR5 rather than the level of CCR5 expressed on cellular targets.

\section{TARGETING CCR5 ANTAGONIST RESISTANT STRAINS}

Due to the different effects that different antagonists have on CCR5, cross resistance is not always a feature of resistant strains. Indeed, in the limited number of samples studied, MVC resistance does not appear to lead to cross resistance whilst resistance to VVC generally does [79, 119, 149]. This indicates there may be use for other CCR5 antagonists, should they enter the market, in therapies against MVC resistant strains. The common mechanism underlying resistance to CCR5 antagonists via an increased dependence on the CCR5 N-terminus indicates a potential target for resistant strains. Using sulfopeptide mimetics of the CCR5 $\mathrm{N}$-terminus, we were able to block the entry of two clinically derived MVC resistant Envs [149, 184]. Others have shown antibodies targeted to the CCR5 N-terminus [127, 148] and to ECL2 can be inhibitory as well [135]. Together, these studies demonstrate that blocking the CCR5 N-terminus could be a useful therapy either pre-emptively administered with CCR5 antagonists or against arising resistant strains. 


\section{CONCLUSION}

In summary, much is known about how HIV-1 evolves resistance to CCR5 antagonists, although a significant amount still remains unclear in this complex field. Certainly, there are two pathways to resistance for HIV-1. Firstly there is outgrowth of pre-existing CXCR4-using variants that are not suppressed by CCR5 antagonists. Secondly, through a complex series of mutations, HIV-1 Envs can evolve to acquire the ability to recognise, bind and utilize the drug/receptor complex. The mutations that confer the ability to use the drug/receptor complex map predominately to the V3 loop of gp120, although additional mutations throughout Env have been identified. There is no signature genetic mutation associated with resistance and each mutation appears to be strain specific, suggesting that the development of genotypic tests for resistance is likely to be problematic. Furthermore, use of the drug/receptor complex is via alterations in the way that Env engages CCR5, principally by becoming more reliant on residues in the CCR5 N-terminus, a region of CCR5 that is not altered by the binding of CCR5 antagonists. This common pathway presents a potential target for inhibiting the emergence of resistant strains. Further studies are required to determine the cross resistance and neutralization profiles, fitness and cell tropism of resistant viruses.

\section{CONFLICT OF INTEREST}

PRG and SRL are members of the ViiV Australia Scientific Advisory Board, and have received honoraria. PRG and SRL have received honoraria from ViiV for travel to conferences, and SRL has received honoraria from ViiV for speaking at and chairing ViiV-sponsored events. PRG has received research funding from ViiV. SRL is a member of the Merck advisory board (international) and has received honoraria. SRL has received honoraria from Merck for speaking at Merck-sponsored events. SRL has received research funding from Merck and ViiV. The other authors declare that they have no competing interests.

\section{ACKNOWLEDGEMENTS}

MR is the recipient of an Australian NHMRC Postdoctoral Training Fellowship. PRG is supported by an Australian Research Council (ARC) Future Fellowship (FT2). SRL is the recipient of a NHMRC Practitioner Fellowship. The authors gratefully acknowledge the contribution to this work of the Victorian Operational Infrastructure Support Program received by the Burnet Institute.

\section{FIGURE LEGENDS}

Figure 1. Structures of CCR5 antagonists A) Cenicriviroc, B) Vicriviroc, C) Aplaviroc and D) Maraviroc

\section{REFERENCES}

1. Gorry P.R.; Ancuta P. Coreceptors and HIV-1 pathogenesis. Curr HIV/AIDS Rep, 2011, 8(1), 45-53.

2. Wilen C.B.; Tilton J.C.; Doms R.W. HIV: cell binding and entry. Cold Spring Harbor perspectives in medicine, 2012, 2(8).

3. Dalgleish A.G.; Beverley P.C.; Clapham P.R.; Crawford D.H.; Greaves M.F.; Weiss R.A. The CD4 (T4) antigen is an essential component of the receptor for the AIDS retrovirus. Nature, 1984, 312(5996), 763-7.

4. Maddon P.J.; Dalgleish A.G.; McDougal J.S.; Clapham P.R.; Weiss R.A.; Axel R. The T4 gene encodes the AIDS virus receptor and is expressed in the immune system and the brain. Cell, 1986, 47(3), 333-48.

5. McDougal J.S.; Kennedy M.S.; Sligh J.M.; Cort S.P.; Mawle A.; Nicholson J.K. Binding of HTLV-III/LAV to T4+ T cells by a complex of the $110 \mathrm{~K}$ viral protein and the T4 molecule. Science, 1986, 231(4736), 382-5.

6. Alkhatib G.; Combadiere C.; Broder C.C.; Feng Y.; Kennedy P.E.; Murphy P.M.; Berger E.A. CC CKR5: a RANTES, MIP-1alpha, MIP-1beta receptor as a fusion cofactor for macrophage-tropic HIV-1. Science, 1996, 272(5270), 1955-8.

7. Dragic T.; Litwin V.; Allaway G.P.; Martin S.R.; Huang Y.; Nagashima K.A.; Cayanan C.; Maddon P.J.; Koup R.A.; Moore J.P.; Paxton W.A. HIV-1 entry into CD4+ cells is mediated by the chemokine receptor CC-CKR-5. Nature, 1996, 381(6584), 667-73.

8. Deng H.; Liu R.; Ellmeier W.; Choe S.; Unutmaz D.; Burkhart M.; Di Marzio P.; Marmon S.; Sutton R.E.; Hill C.M.; Davis C.B.; Peiper S.C.; Schall T.J.; Littman D.R.; Landau N.R. Identification of a major co-receptor for primary isolates of HIV-1. Nature, 1996, 381(6584), 661-6.

9. Choe H.; Farzan M.; Sun Y.; Sullivan N.; Rollins B.; Ponath P.D.; Wu L.; Mackay C.R.; LaRosa G.; Newman W.; Gerard N.; Gerard C.; Sodroski J. The beta-chemokine receptors CCR3 and CCR5 facilitate infection by primary HIV-1 isolates. Cell, 1996, 85(7), 1135-48.

10. Feng Y.; Broder C.C.; Kennedy P.E.; Berger E.A. HIV-1 entry cofactor: functional cDNA cloning of a seventransmembrane, G protein-coupled receptor. Science, 1996, 272(5263), 872-7.

11. Berger E.A.; Doms R.W.; Fenyo E.M.; Korber B.T.; Littman D.R.; Moore J.P.; Sattentau Q.J.; Schuitemaker H.; Sodroski J.; Weiss R.A. A new classification for HIV-1. Nature, 1998, 391(6664), 240.

12. Gorry P.R.; Francella N.; Lewin S.R.; Collman R.G. HIV-1 envelope-receptor interactions required for macrophage infection and implications for current HIV-1 cure strategies. J Leukoc Biol, 2014, 95(1), 71-81.

13. Fenyo E.M.; Fiore J.; Karlsson A.; Albert J.; Scarlatti G. Biological phenotypes of HIV-1 in pathogenesis and transmission. Antibiotics and chemotherapy, 1994, 46, 1824.

14. van't Wout A.B.; Kootstra N.A.; Mulder-Kampinga G.A.; Albrecht-van Lent N.; Scherpbier H.J.; Veenstra J.; Boer K.; Coutinho R.A.; Miedema F.; Schuitemaker H. Macrophage- 
tropic variants initiate human immunodeficiency virus type 1 infection after sexual, parenteral, and vertical transmission. The Journal of clinical investigation, 1994, 94(5), 2060-7.

15. Zhu T.; Mo H.; Wang N.; Nam D.S.; Cao Y.; Koup R.A.; Ho D.D. Genotypic and phenotypic characterization of HIV1 patients with primary infection. Science, 1993, 261(5125), 1179-81.

16. Tersmette M.; Gruters R.A.; de Wolf F.; de Goede R.E.; Lange J.M.; Schellekens P.T.; Goudsmit J.; Huisman H.G.; Miedema F. Evidence for a role of virulent human immunodeficiency virus (HIV) variants in the pathogenesis of acquired immunodeficiency syndrome: studies on sequential HIV isolates. Journal of virology, 1989, 63(5), 2118-25.

17. Schuitemaker H.; Koot M.; Kootstra N.A.; Dercksen M.W.; de Goede R.E.; van Steenwijk R.P.; Lange J.M.; Schattenkerk J.K.; Miedema F.; Tersmette M. Biological phenotype of human immunodeficiency virus type 1 clones at different stages of infection: progression of disease is associated with a shift from monocytotropic to T-cell-tropic virus population. Journal of virology, 1992, 66(3), 1354-60. 18. Koot M.; Keet I.P.; Vos A.H.; de Goede R.E.; Roos M.T.; Coutinho R.A.; Miedema F.; Schellekens P.T.; Tersmette M. Prognostic value of HIV-1 syncytium-inducing phenotype for rate of CD4+ cell depletion and progression to AIDS. Annals of internal medicine, 1993, 118(9), 681-8.

19. Connor R.I.; Sheridan K.E.; Ceradini D.; Choe S.; Landau N.R. Change in coreceptor use correlates with disease progression in HIV-1--infected individuals. The Journal of experimental medicine, 1997, 185(4), 621-8.

20. Bleul C.C.; Wu L.; Hoxie J.A.; Springer T.A.; Mackay C.R. The HIV coreceptors CXCR4 and CCR5 are differentially expressed and regulated on human $\mathrm{T}$ lymphocytes. Proceedings of the National Academy of Sciences of the United States of America, 1997, 94(5), 192530.

21. Lee B.; Sharron M.; Montaner L.J.; Weissman D.; Doms R.W. Quantification of CD4, CCR5, and CXCR4 levels on lymphocyte subsets, dendritic cells, and differentially conditioned monocyte-derived macrophages. Proceedings of the National Academy of Sciences of the United States of America, 1999, 96(9), 5215-20.

22. Lee B.; Sharron M.; Blanpain C.; Doranz B.J.; Vakili J.; Setoh P.; Berg E.; Liu G.; Guy H.R.; Durell S.R.; Parmentier M.; Chang C.N.; Price K.; Tsang M.; Doms R.W. Epitope mapping of CCR5 reveals multiple conformational states and distinct but overlapping structures involved in chemokine and coreceptor function. The Journal of biological chemistry, 1999, 274(14), 9617-26.

23. Wu L.; LaRosa G.; Kassam N.; Gordon C.J.; Heath H.; Ruffing N.; Chen H.; Humblias J.; Samson M.; Parmentier M.; Moore J.P.; Mackay C.R. Interaction of chemokine receptor CCR5 with its ligands: multiple domains for HIV-1 gp120 binding and a single domain for chemokine binding. The Journal of experimental medicine, 1997, 186(8), 137381.
24. Samson M.; LaRosa G.; Libert F.; Paindavoine P.; Detheux M.; Vassart G.; Parmentier M. The second extracellular loop of CCR5 is the major determinant of ligand specificity. The Journal of biological chemistry, 1997, 272(40), 24934-41.

25. Blanpain C.; Doranz B.J.; Bondue A.; Govaerts C.; De Leener A.; Vassart G.; Doms R.W.; Proudfoot A.; Parmentier M. The core domain of chemokines binds CCR5 extracellular domains while their amino terminus interacts with the transmembrane helix bundle. The Journal of biological chemistry, 2003, 278(7), 5179-87.

26. Blanpain C.; Doranz B.J.; Vakili J.; Rucker J.; Govaerts C.; Baik S.S.; Lorthioir O.; Migeotte I.; Libert F.; Baleux F.; Vassart G.; Doms R.W.; Parmentier M. Multiple charged and aromatic residues in CCR5 amino-terminal domain are involved in high affinity binding of both chemokines and HIV-1 Env protein. The Journal of biological chemistry, 1999, 274(49), 34719-27.

27. Blanpain C.; Lee B.; Vakili J.; Doranz B.J.; Govaerts C.; Migeotte I.; Sharron M.; Dupriez V.; Vassart G.; Doms R.W.; Parmentier M. Extracellular cysteines of CCR5 are required for chemokine binding, but dispensable for HIV-1 coreceptor activity. The Journal of biological chemistry, 1999, 274(27), 18902-8.

28. Zhou N.; Luo Z.; Hall J.W.; Luo J.; Han X.; Huang Z. Molecular modeling and site-directed mutagenesis of CCR5 reveal residues critical for chemokine binding and signal transduction. European journal of immunology, 2000, 30(1), 164-73.

29. Farzan M.; Mirzabekov T.; Kolchinsky P.; Wyatt R.; Cayabyab M.; Gerard N.P.; Gerard C.; Sodroski J.; Choe H. Tyrosine sulfation of the amino terminus of CCR5 facilitates HIV-1 entry. Cell, 1999, 96(5), 667-76.

30. Rabut G.E.; Konner J.A.; Kajumo F.; Moore J.P.; Dragic T. Alanine substitutions of polar and nonpolar residues in the amino-terminal domain of CCR5 differently impair entry of macrophage- and dualtropic isolates of human immunodeficiency virus type 1 . Journal of virology, 1998, 72(4), 3464-8.

31. Dragic T.; Trkola A.; Lin S.W.; Nagashima K.A.; Kajumo F.; Zhao L.; Olson W.C.; Wu L.; Mackay C.R.; Allaway G.P.; Sakmar T.P.; Moore J.P.; Maddon P.J. Amino-terminal substitutions in the CCR5 coreceptor impair gp120 binding and human immunodeficiency virus type 1 entry. Journal of virology, 1998, 72(1), 279-85.

32. Huang C.C.; Lam S.N.; Acharya P.; Tang M.; Xiang S.H.; Hussan S.S.; Stanfield R.L.; Robinson J.; Sodroski J.; Wilson I.A.; Wyatt R.; Bewley C.A.; Kwong P.D. Structures of the CCR5 $\mathrm{N}$ terminus and of a tyrosine-sulfated antibody with HIV-1 gp120 and CD4. Science, 2007, 317(5846), 1930-4.

33.Huang C.C.; Tang M.; Zhang M.Y.; Majeed S.; Montabana E.; Stanfield R.L.; Dimitrov D.S.; Korber B.; Sodroski J.; Wilson I.A.; Wyatt R.; Kwong P.D. Structure of a V3-containing HIV-1 gp120 core. Science, 2005, 310(5750), 1025-8. 
34. Cormier E.G.; Dragic T. The crown and stem of the V3 loop play distinct roles in human immunodeficiency virus type 1 envelope glycoprotein interactions with the CCR5 coreceptor. Journal of virology, 2002, 76(17), 8953-7.

35. Farzan M.; Choe H.; Vaca L.; Martin K.; Sun Y.; Desjardins E.; Ruffing N.; Wu L.; Wyatt R.; Gerard N.; Gerard C.; Sodroski J. A tyrosine-rich region in the $\mathrm{N}$ terminus of CCR5 is important for human immunodeficiency virus type 1 entry and mediates an association between gp120 and CCR5. Journal of virology, 1998, 72(2), 1160-4. 36. Cormier E.G.; Persuh M.; Thompson D.A.; Lin S.W.; Sakmar T.P.; Olson W.C.; Dragic T. Specific interaction of CCR5 amino-terminal domain peptides containing sulfotyrosines with HIV-1 envelope glycoprotein gp120. Proceedings of the National Academy of Sciences of the United States of America, 2000, 97(11), 5762-7.

37. Platt E.J.; Kuhmann S.E.; Rose P.P.; Kabat D. Adaptive mutations in the V3 loop of gp120 enhance fusogenicity of human immunodeficiency virus type 1 and enable use of a CCR5 coreceptor that lacks the amino-terminal sulfated region. Journal of virology, 2001, 75(24), 12266-78.

38. Laakso M.M.; Lee F.H.; Haggarty B.; Agrawal C.; Nolan K.M.; Biscone M.; Romano J.; Jordan A.P.; Leslie G.J.; Meissner E.G.; Su L.; Hoxie J.A.; Doms R.W. V3 loop truncations in HIV-1 envelope impart resistance to coreceptor inhibitors and enhanced sensitivity to neutralizing antibodies. PLoS Pathog, 2007, 3(8), e117.

39. Dean M.; Carrington M.; Winkler C.; Huttley G.A.; Smith M.W.; Allikmets R.; Goedert J.J.; Buchbinder S.P.; Vittinghoff E.; Gomperts E.; Donfield S.; Vlahov D.; Kaslow R.; Saah A.; Rinaldo C.; Detels R.; O'Brien S.J. Genetic restriction of HIV-1 infection and progression to AIDS by a deletion allele of the CKR5 structural gene. Hemophilia Growth and Development Study, Multicenter AIDS Cohort Study, Multicenter Hemophilia Cohort Study, San Francisco City Cohort, ALIVE Study. Science, 1996, 273(5283), 1856-62.

40. Huang Y.; Paxton W.A.; Wolinsky S.M.; Neumann A.U.; Zhang L.; He T.; Kang S.; Ceradini D.; Jin Z.; Yazdanbakhsh K.; Kunstman K.; Erickson D.; Dragon E.; Landau N.R.; Phair J.; Ho D.D.; Koup R.A. The role of a mutant CCR5 allele in HIV-1 transmission and disease progression. Nature medicine, 1996, 2(11), 1240-3.

41. Liu R.; Paxton W.A.; Choe S.; Ceradini D.; Martin S.R.; Horuk R.; MacDonald M.E.; Stuhlmann H.; Koup R.A.; Landau N.R. Homozygous defect in HIV-1 coreceptor accounts for resistance of some multiply-exposed individuals to HIV-1 infection. Cell, 1996, 86(3), 367-77.

42. Samson M.; Libert F.; Doranz B.J.; Rucker J.; Liesnard C.; Farber C.M.; Saragosti S.; Lapoumeroulie C.; Cognaux J.; Forceille C.; Muyldermans G.; Verhofstede C.; Burtonboy G.; Georges M.; Imai T.; Rana S.; Yi Y.; Smyth R.J.; Collman R.G.; Doms R.W.; Vassart G.; Parmentier M. Resistance to HIV-1 infection in caucasian individuals bearing mutant alleles of the CCR- 5 chemokine receptor gene. Nature, 1996, 382(6593), 722-5.
43. Michael N.L.; Louie L.G.; Rohrbaugh A.L.; Schultz K.A.; Dayhoff D.E.; Wang C.E.; Sheppard H.W. The role of CCR5 and CCR2 polymorphisms in HIV-1 transmission and disease progression. Nature medicine, 1997, 3(10), 1160-2.

44. Baba M.; Nishimura O.; Kanzaki N.; Okamoto M.; Sawada H.; Iizawa Y.; Shiraishi M.; Aramaki Y.; Okonogi K.; Ogawa Y.; Meguro K.; Fujino M. A small-molecule, nonpeptide CCR5 antagonist with highly potent and selective anti-HIV-1 activity. Proceedings of the National Academy of Sciences of the United States of America, 1999, 96(10), 5698-703.

45. Nishikawa M.; Takashima K.; Nishi T.; Furuta R.A.; Kanzaki N.; Yamamoto Y.; Fujisawa J. Analysis of binding sites for the new small-molecule CCR5 antagonist TAK-220 on human CCR5. Antimicrobial agents and chemotherapy, 2005, 49(11), 4708-15.

46. Kondru R.; Zhang J.; Ji C.; Mirzadegan T.; Rotstein D.; Sankuratri S.; Dioszegi M. Molecular interactions of CCR5 with major classes of small-molecule anti-HIV CCR5 antagonists. Molecular pharmacology, 2008, 73(3), 789-800. 47. Labrecque J.; Metz M.; Lau G.; Darkes M.C.; Wong R.S.; Bogucki D.; Carpenter B.; Chen G.; Li T.; Nan S.; Schols D.; Bridger G.J.; Fricker S.P.; Skerlj R.T. HIV-1 entry inhibition by small-molecule CCR5 antagonists: a combined molecular modeling and mutant study using a high-throughput assay. Virology, 2011, 413(2), 231-43.

48. Baba M.; Takashima K.; Miyake H.; Kanzaki N.; Teshima K.; Wang X.; Shiraishi M.; Iizawa Y. TAK-652 inhibits CCR5-mediated human immunodeficiency virus type 1 infection in vitro and has favorable pharmacokinetics in humans. Antimicrobial agents and chemotherapy, 2005, 49(11), 4584-91.

49. Imamura S.; Ichikawa T.; Nishikawa Y.; Kanzaki N.; Takashima K.; Niwa S.; Iizawa Y.; Baba M.; Sugihara Y. Discovery of a piperidine-4-carboxamide CCR5 antagonist (TAK-220) with highly potent Anti-HIV-1 activity. Journal of medicinal chemistry, 2006, 49(9), 2784-93.

50. Tsamis F.; Gavrilov S.; Kajumo F.; Seibert C.; Kuhmann S.; Ketas T.; Trkola A.; Palani A.; Clader J.W.; Tagat J.R.; McCombie S.; Baroudy B.; Moore J.P.; Sakmar T.P.; Dragic $\mathrm{T}$. Analysis of the mechanism by which the small-molecule CCR5 antagonists SCH-351125 and SCH-350581 inhibit human immunodeficiency virus type 1 entry. Journal of virology, 2003, 77(9), 5201-8.

51. Tremblay C.L.; Giguel F.; Chou T.C.; Dong H.; Takashima K.; Hirsch M.S. TAK-652, a novel CCR5 inhibitor, has favourable drug interactions with other antiretrovirals in vitro. Antiviral therapy, 2005, 10(8), 967-8. 52. Carr M.W.; Roth S.J.; Luther E.; Rose S.S.; Springer T.A. Monocyte chemoattractant protein 1 acts as a Tlymphocyte chemoattractant. Proceedings of the National Academy of Sciences of the United States of America, 1994, 91(9), 3652-6.

53. Gathe J.; Cade J.; DeJesus E. Week-24 Primary Analysis of Cenicriviroc vs Efavirenz, in Combination with Emtricitabine/Tenofovir, in Treatment-naïve HIV-1+ Adults 
with CCR5-tropic Virus, Abstract 106LB. 20th Conference on Retroviruses and Opportunistic Infections; Atlanta, 2013. 54. Marier J.F.; Trinh M.; Pheng L.H.; Palleja S.M.; Martin D.E. Pharmacokinetics and pharmacodynamics of TBR-652, a novel CCR5 antagonist, in HIV-1-infected, antiretroviral treatment-experienced, CCR5 antagonist-naive patients. Antimicrobial agents and chemotherapy, 2011, 55(6), 276874.

55. Lalezari J.; Gathe J.; Brinson C.; Thompson M.; Cohen C.; Dejesus E.; Galindez J.; Ernst J.A.; Martin D.E.; Palleja S.M. Safety, efficacy, and pharmacokinetics of TBR-652, a CCR5/CCR2 antagonist, in HIV-1-infected, treatmentexperienced, CCR5 antagonist-naive subjects. J Acquir Immune Defic Syndr, 2011, 57(2), 118-25.

56. Palani A.; Shapiro S.; Clader J.W.; Greenlee W.J.; Cox K.; Strizki J.; Endres M.; Baroudy B.M. Discovery of 4-[(Z)(4-bromophenyl)- (ethoxyimino)methyl]-1'-[(2,4-dimethyl-3pyridinyl)carbonyl]-4'-methyl-1,4'- bipiperidine N-oxide (SCH 351125): an orally bioavailable human CCR5 antagonist for the treatment of HIV infection. Journal of medicinal chemistry, 2001, 44(21), 3339-42.

57. Strizki J.M.; Xu S.; Wagner N.E.; Wojcik L.; Liu J.; Hou Y.; Endres M.; Palani A.; Shapiro S.; Clader J.W.; Greenlee W.J.; Tagat J.R.; McCombie S.; Cox K.; Fawzi A.B.; Chou C.C.; Pugliese-Sivo C.; Davies L.; Moreno M.E.; Ho D.D.; Trkola A.; Stoddart C.A.; Moore J.P.; Reyes G.R.; Baroudy B.M. SCH-C (SCH 351125), an orally bioavailable, small molecule antagonist of the chemokine receptor CCR5, is a potent inhibitor of HIV-1 infection in vitro and in vivo. Proceedings of the National Academy of Sciences of the United States of America, 2001, 98(22), 12718-23.

58. Finlayson K.; Witchel H.J.; McCulloch J.; Sharkey J. Acquired QT interval prolongation and HERG: implications for drug discovery and development. European journal of pharmacology, 2004, 500(1-3), 129-42.

59. Strizki J.M.; Tremblay C.; Xu S.; Wojcik L.; Wagner N.; Gonsiorek W.; Hipkin R.W.; Chou C.C.; Pugliese-Sivo C.; Xiao Y.; Tagat J.R.; Cox K.; Priestley T.; Sorota S.; Huang W.; Hirsch M.; Reyes G.R.; Baroudy B.M. Discovery and characterization of vicriviroc (SCH 417690), a CCR5 antagonist with potent activity against human immunodeficiency virus type 1. Antimicrobial agents and chemotherapy, 2005, 49(12), 4911-9.

60. Tagat J.R.; McCombie S.W.; Nazareno D.; Labroli M.A.; Xiao Y.; Steensma R.W.; Strizki J.M.; Baroudy B.M.; Cox K.; Lachowicz J.; Varty G.; Watkins R. Piperazine-based CCR5 antagonists as HIV-1 inhibitors. IV. Discovery of 1[(4,6-dimethyl-5-pyrimidinyl)carbonyl]- 4-[4-[2-methoxy1(R)-4-(trifluoromethyl)phenyl]ethyl-3(S)-methyl-1-

piperazinyl]- 4-methylpiperidine (Sch-417690/Sch-D), a potent, highly selective, and orally bioavailable CCR5 antagonist. Journal of medicinal chemistry, 2004, 47(10), 2405-8.

61. Caseiro M.M.; Nelson M.; Diaz R.S.; Gathe J.; de Andrade Neto J.L.; Slim J.; Solano A.; Netto E.M.; Mak C.; Shen J.; Greaves W.; Dunkle L.M.; Vilchez R.A.; Zeinecker
J. Vicriviroc plus optimized background therapy for treatment-experienced subjects with CCR5 HIV-1 infection: final results of two randomized phase III trials. The Journal of infection, 2012, 65(4), 326-35.

62. Maeda K.; Nakata H.; Koh Y.; Miyakawa T.; Ogata H.; Takaoka Y.; Shibayama S.; Sagawa K.; Fukushima D.; Moravek J.; Koyanagi Y.; Mitsuya H. Spirodiketopiperazine-based CCR5 inhibitor which preserves CC-chemokine/CCR5 interactions and exerts potent activity against R5 human immunodeficiency virus type 1 in vitro. Journal of virology, 2004, 78(16), 8654-62.

63. Nakata H.; Maeda K.; Miyakawa T.; Shibayama S.; Matsuo M.; Takaoka Y.; Ito M.; Koyanagi Y.; Mitsuya H. Potent anti-R5 human immunodeficiency virus type 1 effects of a CCR5 antagonist, AK602/ONO4128/GW873140, in a novel human peripheral blood mononuclear cell nonobese diabetic-SCID, interleukin-2 receptor gamma-chainknocked-out AIDS mouse model. Journal of virology, 2005, 79(4), 2087-96.

64. Crabb C. GlaxoSmithKline ends aplaviroc trials. AIDS, 2006, 20(5), 641.

65. Dong M.X.; Lu L.; Li H.; Wang X.; Lu H.; Jiang S.; Dai Q.Y. Design, synthesis, and biological activity of novel 1,4disubstituted piperidine/piperazine derivatives as CCR5 antagonist-based HIV-1 entry inhibitors. Bioorganic \& medicinal chemistry letters, 2012, 22(9), 3284-6.

66. Hu S.; Gu Q.; Wang Z.; Weng Z.; Cai Y.; Dong X.; Hu Y.; Liu T.; Xie X. Design, synthesis, and biological evaluation of novel piperidine-4-carboxamide derivatives as potent CCR5 inhibitors. European journal of medicinal chemistry, 2014, 71, 259-66.

67. Kazmierski W.M.; Danehower S.; Duan M.; Ferris R.G.; Elitzin V.; Minick D.; Sharp M.; Stewart E.; Villeneuve M. Biological and Structural Characterization of Rotamers of CC Chemokine Receptor Type 5 (CCR5) Inhibitor GSK214096. ACS medicinal chemistry letters, 2014, 5(12), 1296-9.

68. Dorr P.; Westby M.; Dobbs S.; Griffin P.; Irvine B.; Macartney M.; Mori J.; Rickett G.; Smith-Burchnell C.; Napier C.; Webster R.; Armour D.; Price D.; Stammen B.; Wood A.; Perros M. Maraviroc (UK-427,857), a potent, orally bioavailable, and selective small-molecule inhibitor of chemokine receptor CCR5 with broad-spectrum anti-human immunodeficiency virus type 1 activity. Antimicrobial agents and chemotherapy, 2005, 49(11), 4721-32.

69. Wood A.; Armour D. The discovery of the CCR5 receptor antagonist, UK-427,857, a new agent for the treatment of HIV infection and AIDS. Progress in medicinal chemistry, 2005, 43, 239-71.

70. Fatkenheuer G.; Nelson M.; Lazzarin A.; Konourina I.; Hoepelman A.I.; Lampiris H.; Hirschel B.; Tebas P.; Raffi F.; Trottier B.; Bellos N.; Saag M.; Cooper D.A.; Westby M.; Tawadrous M.; Sullivan J.F.; Ridgway C.; Dunne M.W.; Felstead S.; Mayer H.; van der Ryst E. Subgroup analyses of maraviroc in previously treated R5 HIV-1 infection. The New England journal of medicine, 2008, 359(14), 1442-55. 
71. Gulick R.M.; Lalezari J.; Goodrich J.; Clumeck N.; DeJesus E.; Horban A.; Nadler J.; Clotet B.; Karlsson A.; Wohlfeiler M.; Montana J.B.; McHale M.; Sullivan J.; Ridgway C.; Felstead S.; Dunne M.W.; van der Ryst E.; Mayer H. Maraviroc for previously treated patients with R5 HIV-1 infection. The New England journal of medicine, 2008, 359(14), 1429-41.

72. Vandekerckhove L.; Verhofstede C.; Vogelaers D. Maraviroc: perspectives for use in antiretroviral-naive HIV1-infected patients. The Journal of antimicrobial chemotherapy, 2009, 63(6), 1087-96.

73. Cooper D.A.; Heera J.; Goodrich J.; Tawadrous M.; Saag M.; Dejesus E.; Clumeck N.; Walmsley S.; Ting N.; Coakley E.; Reeves J.D.; Reyes-Teran G.; Westby M.; Van Der Ryst E.; Ive P.; Mohapi L.; Mingrone H.; Horban A.; Hackman F.; Sullivan J.; Mayer H. Maraviroc versus efavirenz, both in combination with zidovudine-lamivudine, for the treatment of antiretroviral-naive subjects with CCR5-tropic HIV-1 infection. The Journal of infectious diseases, 2010, 201(6), 803-13.

74. Gorry P.R.; Ellett A.; Lewin S.R. Maraviroc. In: Grayson L, Crowe S, McCarthy J, Mills J, Mouton J, Norrby SR, et al., editors. Kucers' The Use of Antibiotics. 6th ed. London: Hodder \& Stoughton; 2010.

75. Tan Q.; Zhu Y.; Li J.; Chen Z.; Han G.W.; Kufareva I.; Li T.; Ma L.; Fenalti G.; Li J.; Zhang W.; Xie X.; Yang H.; Jiang H.; Cherezov V.; Liu H.; Stevens R.C.; Zhao Q.; Wu B. Structure of the CCR5 chemokine receptor-HIV entry inhibitor maraviroc complex. Science, 2013, 341(6152), 1387-90.

76. Dragic T.; Trkola A.; Thompson D.A.; Cormier E.G.; Kajumo F.A.; Maxwell E.; Lin S.W.; Ying W.; Smith S.O.; Sakmar T.P.; Moore J.P. A binding pocket for a small molecule inhibitor of HIV-1 entry within the transmembrane helices of CCR5. Proceedings of the National Academy of Sciences of the United States of America, 2000, 97(10), 5639-44.

77. Bai Q.; Zhang Y.; Li X.; Chen W.; Liu H.; Yao X. Computational study on the interaction between CCR5 and HIV-1 entry inhibitor maraviroc: insight from accelerated molecular dynamics simulation and free energy calculation. Physical chemistry chemical physics : PCCP, 2014, 16(44), 24332-8.

78. Tamamis P.; Floudas C.A. Molecular recognition of CCR5 by an HIV-1 gp120 V3 loop. PloS one, 2014, 9(4), e95767.

79. Tilton J.C.; Wilen C.B.; Didigu C.A.; Sinha R.; Harrison J.E.; Agrawal-Gamse C.; Henning E.A.; Bushman F.D.; Martin J.N.; Deeks S.G.; Doms R.W. A maraviroc-resistant HIV-1 with narrow cross-resistance to other CCR5 antagonists depends on both $\mathrm{N}$-terminal and extracellular loop domains of drug-bound CCR5. Journal of virology, 2010, 84(20), 10863-76.

80. Kramer V.G.; Schader S.M.; Oliveira M.; ColbyGerminario S.P.; Donahue D.A.; Singhroy D.N.; Tressler R.; Sloan R.D.; Wainberg M.A. Maraviroc and other HIV-1 entry inhibitors exhibit a class-specific redistribution effect that results in increased extracellular viral load. Antimicrobial agents and chemotherapy, 2012, 56(8), 415460.

81. Kramer V.G.; Hassounah S.; Colby-Germinario S.P.; Oliveira M.; Lefebvre E.; Mesplede T.; Wainberg M.A. The dual CCR5 and CCR2 inhibitor cenicriviroc does not redistribute HIV into extracellular space: implications for plasma viral load and intracellular DNA decline. The Journal of antimicrobial chemotherapy, 2015, 70(3), 750-6. 82. Fouchier R.A.; Groenink M.; Kootstra N.A.; Tersmette M.; Huisman H.G.; Miedema F.; Schuitemaker H. Phenotype-associated sequence variation in the third variable domain of the human immunodeficiency virus type 1 gp120 molecule. Journal of virology, 1992, 66(5), 3183-7.

83. Isaka Y.; Sato A.; Miki S.; Kawauchi S.; Sakaida H.; Hori T.; Uchiyama T.; Adachi A.; Hayami M.; Fujiwara T.; Yoshie O. Small amino acid changes in the V3 loop of human immunodeficiency virus type 2 determines the coreceptor usage for CXCR4 and CCR5. Virology, 1999, 264(1), 237-43.

84. De Jong J.J.; De Ronde A.; Keulen W.; Tersmette M.; Goudsmit J. Minimal requirements for the human immunodeficiency virus type $1 \mathrm{~V} 3$ domain to support the syncytium-inducing phenotype: analysis by single amino acid substitution. Journal of virology, 1992, 66(11), 6777-80. 85. Cardozo T.; Kimura T.; Philpott S.; Weiser B.; Burger H.; Zolla-Pazner S. Structural basis for coreceptor selectivity by the HIV type 1 V3 loop. AIDS Res Hum Retroviruses, 2007, 23(3), 415-26.

86. Lengauer T.; Sander O.; Sierra S.; Thielen A.; Kaiser R. Bioinformatics prediction of HIV coreceptor usage. Nature biotechnology, 2007, 25(12), 1407-10.

87. Jensen M.A.; Li F.S.; van 't Wout A.B.; Nickle D.C.; Shriner D.; He H.X.; McLaughlin S.; Shankarappa R.; Margolick J.B.; Mullins J.I. Improved coreceptor usage prediction and genotypic monitoring of R5-to-X4 transition by motif analysis of human immunodeficiency virus type 1 env V3 loop sequences. Journal of virology, 2003, 77(24), 13376-88.

88. Cashin K.; Gray L.R.; Harvey K.L.; Perez-Bercoff D.; Lee G.Q.; Sterjovski J.; Roche M.; Demarest J.F.; Drummond F.; Harrigan P.R.; Churchill M.J.; Gorry P.R. Reliable genotypic tropism tests for the major HIV-1 subtypes. Scientific reports, 2015, 5, 8543.

89. Cashin K.; Gray L.R.; Jakobsen M.R.; Sterjovski J.; Churchill M.J.; Gorry P.R. CoRSeqV3-C: a novel HIV-1 subtype C specific V3 sequence based coreceptor usage prediction algorithm. Retrovirology, 2013, 10, 24.

90. De Jong J.; Simon F.; Van der Groen G.; Baan E.; Saragosti S.; Brun-Vezinet F.; Goudsmit J. V3 loop sequence analysis of seven HIV type 1 group $\mathrm{O}$ isolates phenotyped in peripheral blood mononuclear cells and MT-2 cells. AIDS Res Hum Retroviruses, 1996, 12(16), 1503-7.

91. de Jong J.J.; Goudsmit J.; Keulen W.; Klaver B.; Krone W.; Tersmette M.; de Ronde A. Human immunodeficiency 
virus type 1 clones chimeric for the envelope V3 domain differ in syncytium formation and replication capacity. Journal of virology, 1992, 66(2), 757-65.

92. Fouchier R.A.; Brouwer M.; Broersen S.M.; Schuitemaker H. Simple determination of human immunodeficiency virus type 1 syncytium-inducing V3 genotype by PCR. Journal of clinical microbiology, 1995, 33(4), 906-11.

93. Milich L.; Margolin B.; Swanstrom R. V3 loop of the human immunodeficiency virus type 1 Env protein: interpreting sequence variability. Journal of virology, 1993, 67(9), 5623-34.

94. Jansson M.; Backstrom E.; Scarlatti G.; Bjorndal A.; Matsuda S.; Rossi P.; Albert J.; Wigzell H. Length variation of glycoprotein $120 \mathrm{~V} 2$ region in relation to biological phenotypes and coreceptor usage of primary HIV type 1 isolates. AIDS Res Hum Retroviruses, 2001, 17(15), 140514.

95. Huang W.; Toma J.; Fransen S.; Stawiski E.; Reeves J.D.; Whitcomb J.M.; Parkin N.; Petropoulos C.J. Coreceptor tropism can be influenced by amino acid substitutions in the gp41 transmembrane subunit of human immunodeficiency virus type 1 envelope protein. Journal of virology, 2008, 82(11), 5584-93.

96. Boyd M.T.; Simpson G.R.; Cann A.J.; Johnson M.A.; Weiss R.A. A single amino acid substitution in the V1 loop of human immunodeficiency virus type 1 gp120 alters cellular tropism. Journal of virology, 1993, 67(6), 3649-52.

97. Tsibris A.M.; Korber B.; Arnaout R.; Russ C.; Lo C.C.; Leitner T.; Gaschen B.; Theiler J.; Paredes R.; Su Z.; Hughes M.D.; Gulick R.M.; Greaves W.; Coakley E.; Flexner C.; Nusbaum C.; Kuritzkes D.R. Quantitative deep sequencing reveals dynamic HIV-1 escape and large population shifts during CCR5 antagonist therapy in vivo. PloS one, 2009, 4(5), e5683.

98. Archer J.; Braverman M.S.; Taillon B.E.; Desany B.; James I.; Harrigan P.R.; Lewis M.; Robertson D.L. Detection of low-frequency pretherapy chemokine (CXC motif) receptor 4 (CXCR4)-using HIV-1 with ultra-deep pyrosequencing. AIDS, 2009, 23(10), 1209-18.

99. Bunnik E.M.; Swenson L.C.; Edo-Matas D.; Huang W.; Dong W.; Frantzell A.; Petropoulos C.J.; Coakley E.; Schuitemaker H.; Harrigan P.R.; van 't Wout A.B. Detection of Inferred CCR5- and CXCR4-Using HIV-1 Variants and Evolutionary Intermediates Using Ultra-Deep Pyrosequencing. PLoS Pathog, 2011, 7(6), e1002106.

100. Whitcomb J.M.; Huang W.; Fransen S.; Limoli K.; Toma J.; Wrin T.; Chappey C.; Kiss L.D.; Paxinos E.E.; Petropoulos C.J. Development and characterization of a novel single-cycle recombinant-virus assay to determine human immunodeficiency virus type 1 coreceptor tropism. Antimicrobial agents and chemotherapy, 2007, 51(2), 56675.

101. Landovitz R.J.; Angel J.B.; Hoffmann C.; Horst H.; Opravil M.; Long J.; Greaves W.; Fatkenheuer G. Phase II study of vicriviroc versus efavirenz (both with zidovudine/lamivudine) in treatment-naive subjects with HIV-1 infection. The Journal of infectious diseases, 2008, 198(8), 1113-22.

102. Trinh L.; Han D.; Huang W.; Wrin T.; Larson J.; Kiss L.; Coakley E.; Petropoulos C.; Parkin N.; Whitcomb J.; Reeves J. Technical validation of an enhanced sensitivity Trofile HIV coreceptor tropism assay for selecting patients for therapy with entry inhibitors targeting CCR5. Antiviral therapy, 2008, 13(Suppl 3), A128.

103. Su Z.; Gulick R.M.; Krambrink A.; Coakley E.; Hughes M.D.; Han D.; Flexner C.; Wilkin T.J.; Skolnik P.R.; Greaves W.L.; Kuritzkes D.R.; Reeves J.D. Response to vicriviroc in treatment-experienced subjects, as determined by an enhanced-sensitivity coreceptor tropism assay: reanalysis of AIDS clinical trials group A5211. The Journal of infectious diseases, 2009, 200(11), 1724-8.

104. Wilkin T.J.; Goetz M.B.; Leduc R.; Skowron G.; Su Z.; Chan E.S.; Heera J.; Chapman D.; Spritzler J.; Reeves J.D.; Gulick R.M.; Coakley E. Reanalysis of Coreceptor Tropism in HIV-1-Infected Adults Using a Phenotypic Assay with Enhanced Sensitivity. Clin Infect Dis, 2011, 52(7), 925-8.

105. Svicher V.; D'Arrigo R.; Alteri C.; Andreoni M.; Angarano G.; Antinori A.; Antonelli G.; Bagnarelli P.; Baldanti F.; Bertoli A.; Borderi M.; Boeri E.; Bonn I.; Bruzzone B.; Callegaro A.P.; Cammarota R.; Canducci F.; Ceccherini-Silberstein F.; Clementi M.; Monforte A.D.; De Luca A.; Di Biagio A.; Di Gianbenedetto S.; Di Perri G.; Di Pietro M.; Fabeni L.; Fadda G.; Galli M.; Gennari W.; Ghisetti V.; Giacometti A.; Gori A.; Leoncini F.; Maggiolo F.; Maserati R.; Mazzotta F.; Micheli V.; Meini G.; Monno L.; Mussini C.; Nozza S.; Paolucci S.; Parisi S.; Pecorari M.; Pizzi D.; Quirino T.; Re M.C.; Rizzardini G.; Santangelo R.; Soria A.; Stazi F.; Sterrantino G.; Turriziani O.; Viscoli C.; Vullo V.; Lazzarin A.; Perno C.F. Performance of genotypic tropism testing in clinical practice using the enhanced sensitivity version of Trofile as reference assay: results from the OSCAR Study Group. New Microbiol, 2010, 33(3), 195206.

106. McGovern R.A.; Thielen A.; Mo T.; Dong W.; Woods C.K.; Chapman D.; Lewis M.; James I.; Heera J.; Valdez H.; Harrigan P.R. Population-based V3 genotypic tropism assay: a retrospective analysis using screening samples from the A4001029 and MOTIVATE studies. AIDS, 2010, 24(16), 2517-25.

107. Prosperi M.C.; Bracciale L.; Fabbiani M.; Di Giambenedetto S.; Razzolini F.; Meini G.; Colafigli M.; Marzocchetti A.; Cauda R.; Zazzi M.; De Luca A. Comparative determination of HIV-1 co-receptor tropism by Enhanced Sensitivity Trofile, gp120 V3-loop RNA and DNA genotyping. Retrovirology, 2010, 7, 56.

108. Sanchez V.; Masia M.; Robledano C.; Padilla S.; Ramos J.M.; Gutierrez F. Performance of genotypic algorithms for predicting HIV-1 tropism measured against the enhanced-sensitivity Trofile coreceptor tropism assay. Journal of clinical microbiology, 2010, 48(11), 4135-9. 
109. Swenson L.C.; Mo T.; Dong W.W.; Zhong X.; Woods C.K.; Jensen M.A.; Thielen A.; Chapman D.; Lewis M.; James I.; Heera J.; Valdez H.; Harrigan P.R. Deep sequencing to infer HIV-1 co-receptor usage: application to three clinical trials of maraviroc in treatment-experienced patients. The Journal of infectious diseases, 2011, 203(2), 237-45.

110. Saliou A.; Delobel P.; Dubois M.; Nicot F.; Raymond S.; Calvez V.; Masquelier B.; Izopet J. Concordance Between Two Phenotypic Assays and Ultra Deep Pyrosequencing for Determining HIV-1 Tropism. Antimicrob Agents Chemother, 2011.

111. Swenson L.C.; Mo T.; Dong W.W.; Zhong X.; Woods C.K.; Thielen A.; Jensen M.A.; Knapp D.J.; Chapman D.; Portsmouth S.; Lewis M.; James I.; Heera J.; Valdez H.; Harrigan P.R. Deep V3 sequencing for HIV type 1 tropism in treatment-naive patients: a reanalysis of the MERIT trial of maraviroc. Clin Infect Dis, 2011, 53(7), 73242.

112. Vandekerckhove L.; Wensing A.; Kaiser R.; BrunVezinet F.; Clotet B.; De Luca A.; Dressler S.; Garcia F.; Geretti A.; Klimkait T.; Korn K.; Masquelier B.; Perno C.; Schapiro J.; Soriano V.; Sonnerborg A.; Vandamme A.M.; Verhofstede C.; Walter H.; Zazzi M.; Boucher C. European guidelines on the clinical management of HIV-1 tropism testing. Lancet Infect Dis, 2011.

113. Swenson L.C.; Dong W.W.; Mo T.; Demarest J.; Chapman D.; Ellery S.; Heera J.; Valdez H.; Poon A.F.; Harrigan P.R. Use of cellular HIV DNA to predict virologic response to maraviroc: performance of population-based and deep sequencing. Clin Infect Dis, 2013, 56(11), 1659-66.

114. Sierra S.; Dybowski J.N.; Pironti A.; Heider D.; Guney L.; Thielen A.; Reuter S.; Esser S.; Fatkenheuer G.; Lengauer T.; Hoffmann D.; Pfister H.; Jensen B.; Kaiser R. Parameters Influencing Baseline HIV-1 Genotypic Tropism Testing Related to Clinical Outcome in Patients on Maraviroc. PloS one, 2015, 10(5), e0125502.

115. Svicher V.; Alteri C.; Montano M.; Nori A.; D'Arrigo R.; Andreoni M.; Angarano G.; Antinori A.; Antonelli G.; Allice T.; Bagnarelli P.; Baldanti F.; Bertoli A.; Borderi M.; Boeri E.; Bon I.; Bruzzone B.; Barresi R.; Calderisi S.; Callegaro A.P.; Capobianchi M.R.; Gargiulo F.; Castelli F.; Cauda R.; Ceccherini-Silberstein F.; Clementi M.; Chirianni A.; Colafigli M.; D'Arminio Monforte A.; De Luca A.; Di Biagio A.; Di Nicuolo G.; Di Perri G.; Di Santo F.; Fadda G.; Galli M.; Gennari W.; Ghisetti V.; Costantini A.; Gori A.; Gulminetti R.; Leoncini F.; Maffongelli G.; Maggiolo F.; Maserati R.; Mazzotta F.; Meini G.; Micheli V.; Monno L.; Mussini C.; Nozza S.; Paolucci S.; Palu G.; Parisi S.; Parruti G.; Pignataro A.R.; Quirino T.; Re M.C.; Rizzardini G.; Sanguinetti M.; Santangelo R.; Scaggiante R.; Sterrantino G.; Turriziani O.; Vatteroni M.L.; Viscoli C.; Vullo V.; Zazzi M.; Lazzarin A.; Perno C.F. Genotypic testing on HIV-1 DNA as a tool to assess HIV-1 co-receptor usage in clinical practice: results from the DIVA study group. Infection, 2014, 42(1), 61-71.
116. Toma J.; Frantzell A.; Cook J.; Hoh R.; Martin J.; Deeks S.G.; Petropoulos C.; Huang W. Phenotypic Determination of HIV-1 Coreceptor Tropism Using Cellassociated DNA Derived from Blood Samples. 50th Interscience Conference on Antimicrobial Agents and Chemotherapy; Boston, USA: American Society for Microbiology; 2010. p. Abstract H-921.

117. Trkola A.; Kuhmann S.E.; Strizki J.M.; Maxwell E.; Ketas T.; Morgan T.; Pugach P.; Xu S.; Wojcik L.; Tagat J.; Palani A.; Shapiro S.; Clader J.W.; McCombie S.; Reyes G.R.; Baroudy B.M.; Moore J.P. HIV-1 escape from a small molecule, CCR5-specific entry inhibitor does not involve CXCR4 use. Proceedings of the National Academy of Sciences of the United States of America, 2002, 99(1), 395400.

118. Kuhmann S.E.; Pugach P.; Kunstman K.J.; Taylor J.; Stanfield R.L.; Snyder A.; Strizki J.M.; Riley J.; Baroudy B.M.; Wilson I.A.; Korber B.T.; Wolinsky S.M.; Moore J.P. Genetic and phenotypic analyses of human immunodeficiency virus type 1 escape from a smallmolecule CCR5 inhibitor. Journal of virology, 2004, 78(6), 2790-807.

119. Westby M.; Smith-Burchnell C.; Mori J.; Lewis M.; Mosley M.; Stockdale M.; Dorr P.; Ciaramella G.; Perros M. Reduced maximal inhibition in phenotypic susceptibility assays indicates that viral strains resistant to the CCR5 antagonist maraviroc utilize inhibitor-bound receptor for entry. Journal of virology, 2007, 81(5), 2359-71.

120. Marozsan A.J.; Kuhmann S.E.; Morgan T.; Herrera C.; Rivera-Troche E.; Xu S.; Baroudy B.M.; Strizki J.; Moore J.P. Generation and properties of a human immunodeficiency virus type 1 isolate resistant to the small molecule CCR5 inhibitor, SCH-417690 (SCH-D). Virology, 2005, 338(1), 182-99.

121. Ogert R.A.; Wojcik L.; Buontempo C.; Ba L.; Buontempo P.; Ralston R.; Strizki J.; Howe J.A. Mapping resistance to the CCR5 co-receptor antagonist vicriviroc using heterologous chimeric HIV-1 envelope genes reveals key determinants in the C2-V5 domain of gp120. Virology, 2008, 373(2), 387-99.

122. Asin-Milan O.; Chamberland A.; Wei Y.; Haidara A.; Sylla M.; Tremblay C.L. Mutations in variable domains of the HIV-1 envelope gene can have a significant impact on maraviroc and vicriviroc resistance. AIDS research and therapy, 2013, 10(1), 15.

123. Yuan Y.; Maeda Y.; Terasawa H.; Monde K.; Harada S.; Yusa K. A combination of polymorphic mutations in V3 loop of HIV-1 gp120 can confer noncompetitive resistance to maraviroc. Virology, 2011, 413(2), 293-9.

124. Baba M.; Miyake H.; Wang X.; Okamoto M.; Takashima K. Isolation and characterization of human immunodeficiency virus type 1 resistant to the smallmolecule CCR5 antagonist TAK-652. Antimicrobial agents and chemotherapy, 2007, 51(2), 707-15. 
125. Anastassopoulou C.G.; Ketas T.J.; Depetris R.S.; Thomas A.M.; Klasse P.J.; Moore J.P. Resistance of a human immunodeficiency virus type 1 isolate to a small molecule CCR5 inhibitor can involve sequence changes in both gp120 and gp41. Virology, 2011, 413(1), 47-59.

126. Anastassopoulou C.G.; Ketas T.J.; Klasse P.J.; Moore J.P. Resistance to CCR5 inhibitors caused by sequence changes in the fusion peptide of HIV-1 gp41. Proceedings of the National Academy of Sciences of the United States of America, 2009, 106(13), 5318-23.

127. Ogert R.A.; Ba L.; Hou Y.; Buontempo C.; Qiu P.; Duca J.; Murgolo N.; Buontempo P.; Ralston R.; Howe J.A. Structure-function analysis of human immunodeficiency virus type 1 gp120 amino acid mutations associated with resistance to the CCR5 coreceptor antagonist vicriviroc. Journal of virology, 2009, 83(23), 12151-63.

128. Pugach P.; Marozsan A.J.; Ketas T.J.; Landes E.L.; Moore J.P.; Kuhmann S.E. HIV-1 clones resistant to a small molecule CCR5 inhibitor use the inhibitor-bound form of CCR5 for entry. Virology, 2007, 361(1), 212-28.

129. Pugach P.; Ray N.; Klasse P.J.; Ketas T.J.; Michael E.; Doms R.W.; Lee B.; Moore J.P. Inefficient entry of vicriviroc-resistant $\mathrm{HIV}-1$ via the inhibitor-CCR5 complex at low cell surface CCR5 densities. Virology, 2009, 387(2), 296-302.

130. Petropoulos C.; Huang W.; Toma J.; Fransen S.; Bonhoeffer S.; Whitcomb J. Resistance to HIV-1 Entry Inhibitors May Occur by Multiple Molecular Mechanisms. Antiviral therapy, 2004, 9(S25).

131. Tilton J.C.; Amrine-Madsen H.; Miamidian J.L.; Kitrinos K.M.; Pfaff J.; Demarest J.F.; Ray N.; Jeffrey J.L.; Labranche C.C.; Doms R.W. HIV type 1 from a patient with baseline resistance to CCR5 antagonists uses drug-bound receptor for entry. AIDS Res Hum Retroviruses, 2010, 26(1), 13-24.

132. Roche M.; Jakobsen M.R.; Sterjovski J.; Ellett A.; Posta F.; Lee B.; Jubb B.; Westby M.; Lewin S.R.; Ramsland P.A.; Churchill M.J.; Gorry P.R. HIV-1 escape from the CCR5 antagonist maraviroc associated with an altered and less efficient mechanism of gp120-CCR5 engagement that attenuates macrophage-tropism. Journal of virology, 2011, 85, 4330-42.

133. Berro R.; Klasse P.J.; Lascano D.; Flegler A.; Nagashima K.A.; Sanders R.W.; Sakmar T.P.; Hope T.J.; Moore J.P. Multiple CCR5 conformations on the cell surface are used differentially by human immunodeficiency viruses resistant or sensitive to CCR5 inhibitors. Journal of virology, 2011.

134. Berro R.; Sanders R.W.; Lu M.; Klasse P.J.; Moore J.P. Two HIV-1 variants resistant to small molecule CCR5 inhibitors differ in how they use CCR5 for entry. PLoS Pathog, 2009, 5(8), e1000548.

135. Latinovic O.; Reitz M.; Le N.M.; Foulke J.S.; Fatkenheuer G.; Lehmann C.; Redfield R.R.; Heredia A. CCR5 antibodies HGS004 and HGS101 preferentially inhibit drug-bound CCR5 infection and restore drug sensitivity of
Maraviroc-resistant HIV-1 in primary cells. Virology, 2011, 411(1), 32-40.

136. Gulick R.M.; Su Z.; Flexner C.; Hughes M.D.; Skolnik P.R.; Wilkin T.J.; Gross R.; Krambrink A.; Coakley E.; Greaves W.L.; Zolopa A.; Reichman R.; Godfrey C.; Hirsch M.; Kuritzkes D.R. Phase 2 study of the safety and efficacy of vicriviroc, a CCR5 inhibitor, in HIV-1-Infected, treatment-experienced patients: AIDS clinical trials group 5211. The Journal of infectious diseases, 2007, 196(2), 30412.

137. Demarest J.F.; Amrine-Madsen H.; Irlbeck D.M.; Kitrinos K.M. Virologic failure in first-line human immunodeficiency virus therapy with a CCR5 entry inhibitor, aplaviroc, plus a fixed-dose combination of lamivudine-zidovudine: nucleoside reverse transcriptase inhibitor resistance regardless of envelope tropism. Antimicrobial agents and chemotherapy, 2009, 53(3), 111623.

138. Kitrinos K.M.; Amrine-Madsen H.; Irlbeck D.M.; Word J.M.; Demarest J.F. Virologic failure in therapy-naive subjects on aplaviroc plus lopinavir-ritonavir: detection of aplaviroc resistance requires clonal analysis of envelope. Antimicrobial agents and chemotherapy, 2009, 53(3), 112431.

139. Westby M.; Lewis M.; Whitcomb J.; Youle M.; Pozniak A.L.; James I.T.; Jenkins T.M.; Perros M.; van der Ryst E. Emergence of CXCR4-using human immunodeficiency virus type 1 (HIV-1) variants in a minority of HIV-1-infected patients following treatment with the CCR5 antagonist maraviroc is from a pretreatment CXCR4-using virus reservoir. Journal of virology, 2006, 80(10), 4909-20.

140. Swenson L.C.; Chui C.K.; Brumme C.J.; Chan D.; Woods C.K.; Mo T.; Dong W.; Chapman D.; Lewis M.; Demarest J.F.; James I.; Portsmouth S.; Goodrich J.; Heera J.; Valdez H.; Harrigan P.R. Genotypic analysis of the V3 region of HIV from virologic nonresponders to maraviroccontaining regimens reveals distinct patterns of failure. Antimicrobial agents and chemotherapy, 2013, 57(12), 6122-30.

141. Westby M.; van der Ryst E. CCR5 antagonists: host-targeted antiviral agents for the treatment of HIV infection, 4 years on. Antivir Chem Chemother, 2010, 20(5), 179-92.

142. Gathe J D.R., Fatkenheuer G, Zeinecker J, Mak C, Vilchez R.A, Greaves W, Kumar S, Onyebuchi C, Dunkle L.M, editor Phase 3 trials of vicriviroc in treatmentexperienced subjects demonstrate safety but not significantly superior efficacy over potent background regimens alone. 17th Conference on Retroviruses and Opportunistic Infections 2010 16-19 February; San Fransisco, CA, USA. 143. Suleiman J.; Zingman B.S.; Diaz R.S.; Madruga J.V.; DeJesus E.; Slim J.; Mak C.; Lee E.; McCarthy M.C.; Dunkle L.M.; Walmsley S. Vicriviroc in combination therapy with an optimized regimen for treatmentexperienced subjects: 48-week results of the VICTOR-E1 
phase 2 trial. The Journal of infectious diseases, 2010, 201(4), 590-9.

144. McNicholas P.; Wei Y.; Whitcomb J.; Greaves W.; Black T.A.; Tremblay C.L.; Strizki J.M. Characterization of emergent HIV resistance in treatment-naive subjects enrolled in a vicriviroc phase 2 trial. The Journal of infectious diseases, 2010, 201(10), 1470-80.

145. McNicholas P.M.; Mann P.A.; Wojcik L.; Phd P.Q.; Lee E.; McCarthy M.; Shen J.; Black T.A.; Strizki J.M. Mapping and characterization of vicriviroc resistance mutations from HIV-1 isolated from treatment-experienced subjects enrolled in a phase II study (VICTOR-E1). J Acquir Immune Defic Syndr, 2011, 56(3), 222-9.

146. Tsibris A.M.; Sagar M.; Gulick R.M.; Su Z.; Hughes M.; Greaves W.; Subramanian M.; Flexner C.; Giguel F.; Leopold K.E.; Coakley E.; Kuritzkes D.R. In vivo emergence of vicriviroc resistance in a human immunodeficiency virus type 1 subtype C-infected subject. Journal of virology, 2008, 82(16), 8210-4.

147. Henrich T.J.; Tsibris A.M.; Lewine N.R.; Konstantinidis I.; Leopold K.E.; Sagar M.; Kuritzkes D.R. Evolution of CCR5 antagonist resistance in an HIV-1 subtype C clinical isolate. J Acquir Immune Defic Syndr, 2010, 55(4), 420-7.

148. Ogert R.A.; Hou Y.; Ba L.; Wojcik L.; Qiu P.; Murgolo N.; Duca J.; Dunkle L.M.; Ralston R.; Howe J.A. Clinical resistance to vicriviroc through adaptive V3 loop mutations in HIV-1 subtype D gp120 that alter interactions with the N-terminus and ECL2 of CCR5. Virology, 2010, 400(1), 145-55.

149. Roche M.; Salimi H.; Duncan R.; Wilkinson B.L.; Chikere K.; Moore M.S.; Webb N.E.; Zappi H.; Sterjovski J.; Flynn J.K.; Ellett A.; Gray L.R.; Lee B.; Jubb B.; Westby M.; Ramsland P.A.; Lewin S.R.; Payne R.J.; Churchill M.J.; Gorry P.R. A common mechanism of clinical HIV-1 resistance to the CCR5 antagonist maraviroc despite divergent resistance levels and lack of common gp120 resistance mutations. Retrovirology, 2013, 10, 43.

150. Putcharoen O.; Lee S.H.; Henrich T.J.; Hu Z.; Vanichanan J.; Coakley E.; Greaves W.; Gulick R.M.; Kuritzkes D.R.; Tsibris A.M. HIV-1 clinical isolates resistant to CCR5 antagonists exhibit delayed entry kinetics that are corrected in the presence of drug. Journal of virology, 2012, 86(2), 1119-28.

151. Pfizer I. Maraviroc Tablets NDA 22-128 Antiviral Drugs Advisory Committee (ADVAC) briefing document. 2007 24th April 2007. Report No.

152. Pfaff J.M.; Wilen C.B.; Harrison J.E.; Demarest J.F.; Lee B.; Doms R.W.; Tilton J.C. HIV-1 resistance to CCR5 antagonists associated with highly efficient use of CCR5 and altered tropism on primary CD4+ T cells. Journal of virology, 2010, 84(13), 6505-14.

153. Henrich T.J.; Lewine N.R.; Lee S.H.; Rao S.S.; Berro R.; Gulick R.M.; Moore J.P.; Tsibris A.M.; Kuritzkes D.R. Differential use of CCR5 by HIV-1 clinical isolates resistant to small-molecule CCR5 antagonists. Antimicrobial agents and chemotherapy, 2012, 56(4), 1931-5.

154. Isaacman-Beck J.; Hermann E.A.; Yi Y.; Ratcliffe S.J.; Mulenga J.; Allen S.; Hunter E.; Derdeyn C.A.; Collman R.G. Heterosexual transmission of human immunodeficiency virus type 1 subtype C: Macrophage tropism, alternative coreceptor use, and the molecular anatomy of CCR5 utilization. Journal of virology, 2009, 83(16), 8208-20.

155. Karlsson I.; Antonsson L.; Shi Y.; Oberg M.; Karlsson A.; Albert J.; Olde B.; Owman C.; Jansson M.; Fenyo E.M. Coevolution of RANTES sensitivity and mode of CCR5 receptor use by human immunodeficiency virus type 1 of the R5 phenotype. Journal of virology, 2004, 78(21), 11807-15.

156. Sterjovski J.; Roche M.; Churchill M.J.; Ellett A.; Farrugia W.; Gray L.R.; Cowley D.; Poumbourios P.; Lee B.; Wesselingh S.L.; Cunningham A.L.; Ramsland P.A.; Gorry P.R. An altered and more efficient mechanism of CCR5 engagement contributes to macrophage tropism of CCR5-using HIV-1 envelopes. Virology, 2010, 404(2), 26978.

157. Harrison J.E.; Lynch J.B.; Sierra L.J.; Blackburn L.A.; Ray N.; Collman R.G.; Doms R.W. Baseline resistance of primary human immunodeficiency virus type 1 strains to the CXCR4 inhibitor AMD3100. Journal of virology, 2008, 82(23), 11695-704.

158. Delobel P.; Cazabat M.; Saliou A.; Loiseau C.; Coassin L.; Raymond S.; Requena M.; Marchou B.; Massip P.; Izopet J. Primary resistance of CCR5-tropic HIV-1 to maraviroc cannot be predicted by the V3 sequence. The Journal of antimicrobial chemotherapy, 2013, 68(11), 250614.

159. Roche M.; Jakobsen M.R.; Ellett A.; Salimiseyedabad H.; Jubb B.; Westby M.; Lee B.; Lewin S.R.; Churchill M.J.; Gorry P.R. HIV-1 predisposed to acquiring resistance to maraviroc (MVC) and other CCR5 antagonists in vitro has an inherent, low-level ability to utilize MVC-bound CCR5 for entry. Retrovirology, 2011, 8, 89.

160. Johnston S.H.; Lobritz M.A.; Nguyen S.; Lassen K.; Delair S.; Posta F.; Bryson Y.J.; Arts E.J.; Chou T.; Lee B. A quantitative affinity-profiling system that reveals distinct CD4/CCR5 usage patterns among human immunodeficiency virus type 1 and simian immunodeficiency virus strains. Journal of virology, 2009, 83(21), 11016-26.

161. Ping L.H.; Joseph S.B.; Anderson J.A.; Abrahams M.R.; Salazar-Gonzalez J.F.; Kincer L.P.; Treurnicht F.K.; Arney L.; Ojeda S.; Zhang M.; Keys J.; Potter E.L.; Chu H.; Moore P.; Salazar M.G.; Iyer S.; Jabara C.; Kirchherr J.; Mapanje C.; Ngandu N.; Seoighe C.; Hoffman I.; Gao F.; Tang Y.; Labranche C.; Lee B.; Saville A.; Vermeulen M.; Fiscus S.; Morris L.; Karim S.A.; Haynes B.F.; Shaw G.M.; Korber B.T.; Hahn B.H.; Cohen M.S.; Montefiori D.; Williamson C.; Swanstrom R.; Study C.A.I.; the Center for H.I.V.A.V.I.C. Comparison of viral Env proteins from acute 
and chronic infections with subtype $\mathrm{C}$ human immunodeficiency virus type 1 identifies differences in glycosylation and CCR5 utilization and suggests a new strategy for immunogen design. Journal of virology, 2013, 87(13), 7218-33.

162. Parker Z.F.; Iyer S.S.; Wilen C.B.; Parrish N.F.; Chikere K.C.; Lee F.H.; Didigu C.A.; Berro R.; Klasse P.J.; Lee B.; Moore J.P.; Shaw G.M.; Hahn B.H.; Doms R.W. Transmitted/founder and chronic HIV-1 envelope proteins are distinguished by differential utilization of CCR5. Journal of virology, 2013, 87(5), 2401-11.

163. Lassen K.G.; Lobritz M.A.; Bailey J.R.; Johnston S.; Nguyen S.; Lee B.; Chou T.; Siliciano R.F.; Markowitz M.; Arts E.J. Elite suppressor-derived HIV-1 envelope glycoproteins exhibit reduced entry efficiency and kinetics. PLoS Pathog, 2009, 5(4), e1000377.

164. Gray L.; Sterjovski J.; Churchill M.; Ellery P.; Nasr N.; Lewin S.R.; Crowe S.M.; Wesselingh S.L.; Cunningham A.L.; Gorry P.R. Uncoupling coreceptor usage of human immunodeficiency virus type 1 (HIV-1) from macrophage tropism reveals biological properties of CCR5-restricted HIV-1 isolates from patients with acquired immunodeficiency syndrome. Virology, 2005, 337(2), 38498.

165. Anastassopoulou C.G.; Marozsan A.J.; Matet A.; Snyder A.D.; Arts E.J.; Kuhmann S.E.; Moore J.P. Escape of HIV-1 from a small molecule CCR5 inhibitor is not associated with a fitness loss. PLoS Pathog, 2007, 3(6), e79.

166. Vaidya N.K.; Rong L.; Marconi V.C.; Kuritzkes D.R.; Deeks S.G.; Perelson A.S. Treatment-mediated alterations in HIV fitness preserve CD4+ T cell counts but have minimal effects on viral load. PLoS computational biology, 2010, 6(11), e1001012.

167. Lu J.; Sista P.; Giguel F.; Greenberg M.; Kuritzkes D.R. Relative replicative fitness of human immunodeficiency virus type 1 mutants resistant to enfuvirtide (T-20). Journal of virology, 2004, 78(9), 462837.

168. Pugach P.; Ketas T.J.; Michael E.; Moore J.P. Neutralizing antibody and anti-retroviral drug sensitivities of HIV-1 isolates resistant to small molecule CCR5 inhibitors. Virology, 2008, 377(2), 401-7.

169. Alkhatib G.; Locati M.; Kennedy P.E.; Murphy P.M.; Berger E.A. HIV-1 coreceptor activity of CCR5 and its inhibition by chemokines: independence from $G$ protein signaling and importance of coreceptor downmodulation. Virology, 1997, 234(2), 340-8.

170. Yoshimura K.; Harada S.; Boonchawalit S.; Kawanami Y.; Matsushita S. Impact of maraviroc-resistant and low-CCR5-adapted mutations induced by in vitro passage on sensitivity to anti-envelope neutralizing antibodies. The Journal of general virology, 2014, 95(Pt 8), 1816-26.

171. Richman D.D.; Wrin T.; Little S.J.; Petropoulos C.J. Rapid evolution of the neutralizing antibody response to HIV type 1 infection. Proceedings of the National Academy of Sciences of the United States of America, 2003, 100(7), 4144-9.

172. Koning F.A.; Koevoets C.; van der Vorst T.J.; Schuitemaker H. Sensitivity of primary R5 HTV-1 to inhibition by RANTES correlates with sensitivity to smallmolecule R5 inhibitors. Antiviral therapy, 2005, 10(2), 2317.

173. Etemad B.; Fellows A.; Kwambana B.; Kamat A.; Feng Y.; Lee S.; Sagar M. Human immunodeficiency virus type 1 V1-to-V5 envelope variants from the chronic phase of infection use CCR5 and fuse more efficiently than those from early after infection. Journal of virology, 2009, 83(19), 9694-708.

174. Repits J.; Oberg M.; Esbjornsson J.; Medstrand P.; Karlsson A.; Albert J.; Fenyo E.M.; Jansson M. Selection of human immunodeficiency virus type 1 R5 variants with augmented replicative capacity and reduced sensitivity to entry inhibitors during severe immunodeficiency. The Journal of general virology, 2005, 86(Pt 10), 2859-69.

175. Chatziandreou N.; Arauz A.B.; Freitas I.; Nyein P.H.; Fenton G.; Mehta S.H.; Kirk G.D.; Sagar M. Sensitivity changes over the course of infection increases the likelihood of resistance against fusion but not CCR5 receptor blockers. AIDS Res Hum Retroviruses, 2012, 28(12), 158493.

176. Grossman Z.; Meier-Schellersheim M.; Paul W.E.; Picker L.J. Pathogenesis of HIV infection: what the virus spares is as important as what it destroys. Nature medicine, 2006, 12(3), 289-95.

177. Okoye A.; Meier-Schellersheim M.; Brenchley J.M.; Hagen S.I.; Walker J.M.; Rohankhedkar M.; Lum R.; Edgar J.B.; Planer S.L.; Legasse A.; Sylwester A.W.; Piatak M.; Lifson J.D.; Maino V.C.; Sodora D.L.; Douek D.C.; Axthelm M.K.; Grossman Z.; Picker L.J. Progressive CD4(+) central,Äìmemory T cell decline results in CD4(+) effector,Äìmemory insufficiency and overt disease in chronic SIV infection. The Journal of experimental medicine, 2007, 204(9), 2171-85.

178. Chomont N.; El-Far M.; Ancuta P.; Trautmann L.; Procopio F.A.; Yassine-Diab B.; Boucher G.; Boulassel M.R.; Ghattas G.; Brenchley J.M.; Schacker T.W.; Hill B.J.; Douek D.C.; Routy J.P.; Haddad E.K.; Sekaly R.P. HIV reservoir size and persistence are driven by $\mathrm{T}$ cell survival and homeostatic proliferation. Nature medicine, 2009, 15(8), 893-900.

179. Flynn J.K.; Gorry P.R. Stem memory $\mathrm{T}$ cells (TSCM) - their role in cancer and HIV immunotherapies. Clinical \& Translational Immunology, 2014, 3, e20.

180. Flynn J.K.; Paukovics G.; Moore M.S.; Ellett A.; Gray L.R.; Duncan R.; Salimi H.; Jubb B.; Westby M.; Purcell D.F.; Lewin S.R.; Lee B.; Churchill M.J.; Gorry P.R.; Roche M. The magnitude of HIV-1 resistance to the CCR5 antagonist maraviroc may impart a differential alteration in HIV-1 tropism for macrophages and T-cell subsets. Virology, 2013, 442(1), 51-8. 
181. Cashin K.; Paukovics G.; Jakobsen M.R.; Ostergaard L.; Churchill M.J.; Gorry P.R.; Flynn J.K. Differences in coreceptor specificity contribute to alternative tropism of HIV-1 subtype C for CD4 + T-cell subsets, including stem cell memory T-cells. Retrovirology, 2014, 11(1), 97.

182. Gorry P.R.; Ancuta P. Coreceptors and HIV-1 pathogenesis. Curr HIV/AIDS Rep, 2011, 8, 45-53.

183. Flynn J.K.; Paukovics G.; Cashin K.; Borm K.; Ellett A.; Roche M.; Jakobsen M.R.; Churchill M.J.; Gorry P.R. Quantifying Susceptibility of CD4+ Stem Memory TCells to Infection by Laboratory Adapted and Clinical HIV-1 Strains. Viruses, 2014, 6(2), 709-26.
184. Liu X.; Malins L.R.; Roche M.; Sterjovski J.; Duncan R.; Garcia M.L.; Barnes N.C.; Anderson D.A.; Stone M.J.; Gorry P.R.; Payne R.J. Site-selective solid-phase synthesis of a CCR5 sulfopeptide library to interrogate HIV binding and entry. ACS chemical biology, 2014, 9(9), 207481. 


\section{University Library}

\section{- M M N E R VA A gateway to Melbourne's research publications}

Minerva Access is the Institutional Repository of The University of Melbourne

Author/s:

Roche, M;Borm, K;Flynn, JK;Lewin, SR;Churchill, MJ;Gorry, PR

Title:

Molecular Gymnastics: Mechanisms of HIV-1 Resistance to CCR5 Antagonists and Impact on Virus Phenotypes

Date:

2016-01-01

Citation:

Roche, M., Borm, K., Flynn, J. K., Lewin, S. R., Churchill, M. J. \& Gorry, P. R. (2016). Molecular Gymnastics: Mechanisms of HIV-1 Resistance to CCR5 Antagonists and Impact on Virus Phenotypes. CURRENT TOPICS IN MEDICINAL CHEMISTRY, 16 (10), pp.1091-1106. https://doi.org/10.2174/1568026615666150901114724.

Persistent Link:

http://hdl.handle.net/11343/123537 